\title{
Diverse Defenses: A Perspective Comparing Dipteran Piwi-piRNA Pathways
}

\author{
Stephanie Gamez ${ }^{1}{ }^{\mathbb{D}}$, Satyam Srivastav ${ }^{2} \mathbb{C}$, Omar S. Akbari ${ }^{1}$ and Nelson C. Lau ${ }^{3, *}$ \\ 1 Division of Biological Sciences, Section of Cell and Developmental Biology, University of California, \\ San Diego, CA 92093, USA; sgamez@ucsd.edu (S.G.); oakbari@ucsd.edu (O.S.A.) \\ 2 Department of Molecular Biology and Genetics, Cornell University, Ithaca, NY 14853-2703, USA; \\ sps257@cornell.edu \\ 3 Department of Biochemistry and Genome Science Institute, Boston University School of Medicine, Boston, \\ MA 02118, USA \\ * Correspondence: nclau@bu.edu
}

Received: 2 September 2020; Accepted: 23 September 2020; Published: 27 September 2020

\begin{abstract}
Animals face the dual threat of virus infections hijacking cellular function and transposons proliferating in germline genomes. For insects, the deeply conserved RNA interference (RNAi) pathways and other chromatin regulators provide an important line of defense against both viruses and transposons. For example, this innate immune system displays adaptiveness to new invasions by generating cognate small RNAs for targeting gene silencing measures against the viral and genomic intruders. However, within the Dipteran clade of insects, Drosophilid fruit flies and Culicids mosquitoes have evolved several unique mechanistic aspects of their RNAi defenses to combat invading transposons and viruses, with the Piwi-piRNA arm of the RNAi pathways showing the greatest degree of novel evolution. Whereas central features of Piwi-piRNA pathways are conserved between Drosophilids and Culicids, multiple lineage-specific innovations have arisen that may reflect distinct genome composition differences and specific ecological and physiological features dividing these two branches of Dipterans. This perspective review focuses on the most recent findings illuminating the Piwi/piRNA pathway distinctions between fruit flies and mosquitoes, and raises open questions that need to be addressed in order to ameliorate human diseases caused by pathogenic viruses that mosquitoes transmit as vectors.
\end{abstract}

Keywords: transposons; piRNA; Drosophilids; mosquitoes

\section{Introduction}

In the Dipteran clade of insects, arguably the most widely studied groups of species are the Drosophilidae fruit flies and the Culicidae mosquitoes. Whereas Drosophila genetics pioneered fundamental basic understanding of development, genetics, genomics, and insights into human disease-causing genes, mosquitoes have been studied intensely because they transmit serious pathogens that affect humans like Plasmodium falciparum (malaria parasite), West Nile virus (WNV), chikungunya virus (CHIKV), Yellow fever virus (YFV), dengue (DENV), and Zika (ZIKV) viruses. Many critical discoveries within the RNA interference (RNAi) and genome editing revolutions were first pioneered in Drosophila because of its experimental advantages, and this progress is now permeating to the mosquito field. Genetic mechanisms and genomics studies of transposons established in Drosophila [1-3] are beginning to add to the extensive virology literature in mosquitoes $[4,5]$.

Several transposons are characterized as "endogenous retroviruses" (ERVs), indicating the relation between transposons and viruses as invaders of animal cells that share many of the same genetic elements as viruses $[6,7]$. The distinctions between these invaders are that transposons are vertically 
transmitted from parent to offspring genomes and replicating themselves to new genomic locations, whereas viruses replicate in the cytoplasm or nucleus and transmit horizontally as budded particles between distinct individuals. We refer the reader to several reviews covering the rich biology of transposons and their relationship to viruses [8-11].

Animals have evolved defense mechanisms under immense evolutionary pressure to repress transposons and viruses in order to survive and reproduce as species, whereas the invaders need to evade these host defense mechanisms. This molecular "arms race" between the invading viruses and transposons and the animal host defenses is constantly ongoing at a heightened evolutionary pace to promote lineage specific genetic innovations [12-14]. RNAi is critically one of these host defense mechanisms conserved throughout nearly all branches of life to defend against transposons and viruses, and the general biochemical features of RNAi are also extensively covered in these other reviews [15-18].

The specific purpose of this review is to summarize, compare, and contrast how RNAi pathways have evolved rapidly between Drosophilids and Culicids to defend against transposons and viruses. In this review we raise some key questions (Box 1), we primarily discuss the Piwi protein and Piwi-interacting RNA (piRNA) pathways in these two Dipteran lineages and we touch upon the endogenous small interfering RNA (endo-siRNA), a canonical branch of RNAi. Although the microRNA (miRNA) branch of the RNAi pathway critically regulates gene expression during development for all animals $[19,20]$, the role of microRNAs in transposon or virus suppression in insects has been more limited to a few studies [21-23], or has courted controversy [24-26]. We refer to [27] for further reading on this topic.

Box 1. Key open questions regarding the Piwi/piRNA pathway differences between Drosophilids fruit flies and Culicids mosquitoes.

1. What additional transposons', viruses', and genes' silencing roles might explain the expansion of Piwi genes in culicine mosquitoes but not in anopheline mosquitoes and Drosophilids?

2. Can mosquito Piwi pathways cause transcriptional chromatin silencing like in Drosophilids?

3. What drives the immense diversity of piRNAs between mosquito species and strains, different transposons in their piRNA cluster loci or different states of virus infections?

4. Can we harness or manipulate the mosquito Piwi/piRNA pathways to develop novel antiviral effectors for vector control strategies?

Other reviews have extensively discussed the RNAi/endo-siRNA [28-32] and Piwi/piRNA pathways [33-37] in animals, but here we will highlight the core facet of the two parallel sets of processing factors and effector Argonaute-family proteins defining the two classes of small RNAs in insects (Figure 1A). Whereas the miRNAs are processed by the RNAse III enzyme DICER1 and loaded into AGO1, endo-siRNAs are often processed by a second RNAse III enzyme DICER2 and loaded into AGO2 [38-40]. A much more complicated set of RNA export factors and nucleases completely distinct from DICERs process piRNAs that are then loaded into multiple Piwi proteins, such as PIWI, AUBERGINE, and AGO3 in Drosophila [34,41-44].

Although animal small RNA classes are technically defined/annotated by criteria different from originating locus and protein they are bound to [45], read length and sequence matching to existing databases can serve as an approximate proxy of the proportions of these small RNA classes (Figure 1B). For example, we observed varying proportions of miRNAs, endo-siRNAs, and piRNAs that form distinct profiles between Drosophilids and Culicidae [46]. These distinct small RNA class profiles may reflect the specific genomic, physiological, and evolutionary divergence between Drosophilids and Culicidae. Alternatively, different tissue expression patterns and unique geography of animals with different arbovirus infection statuses may also cause distinct small RNA profiles. 
A

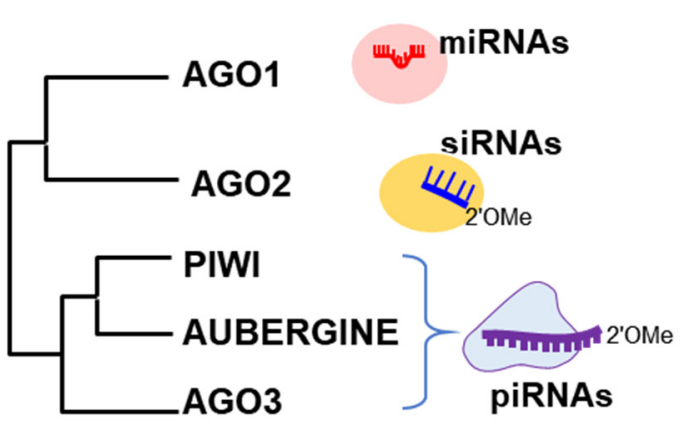

B - Total small RNAs $=$ microRnAs - TE sRNAs $=$ Virus sRNAs

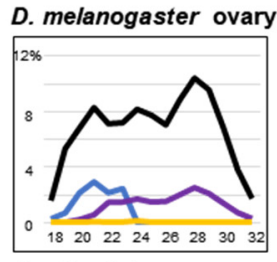

A. albopictus ovary

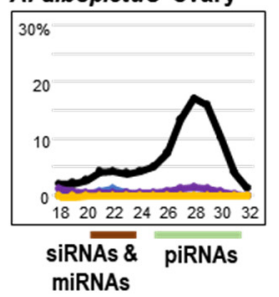

D. melanogaster female soma

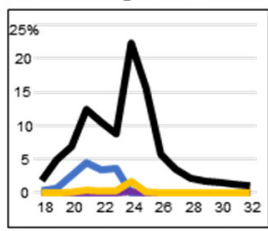

A. albopictus female soma

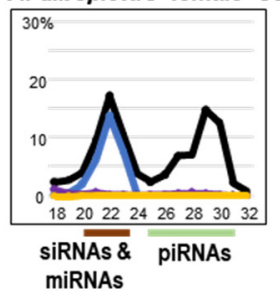

C
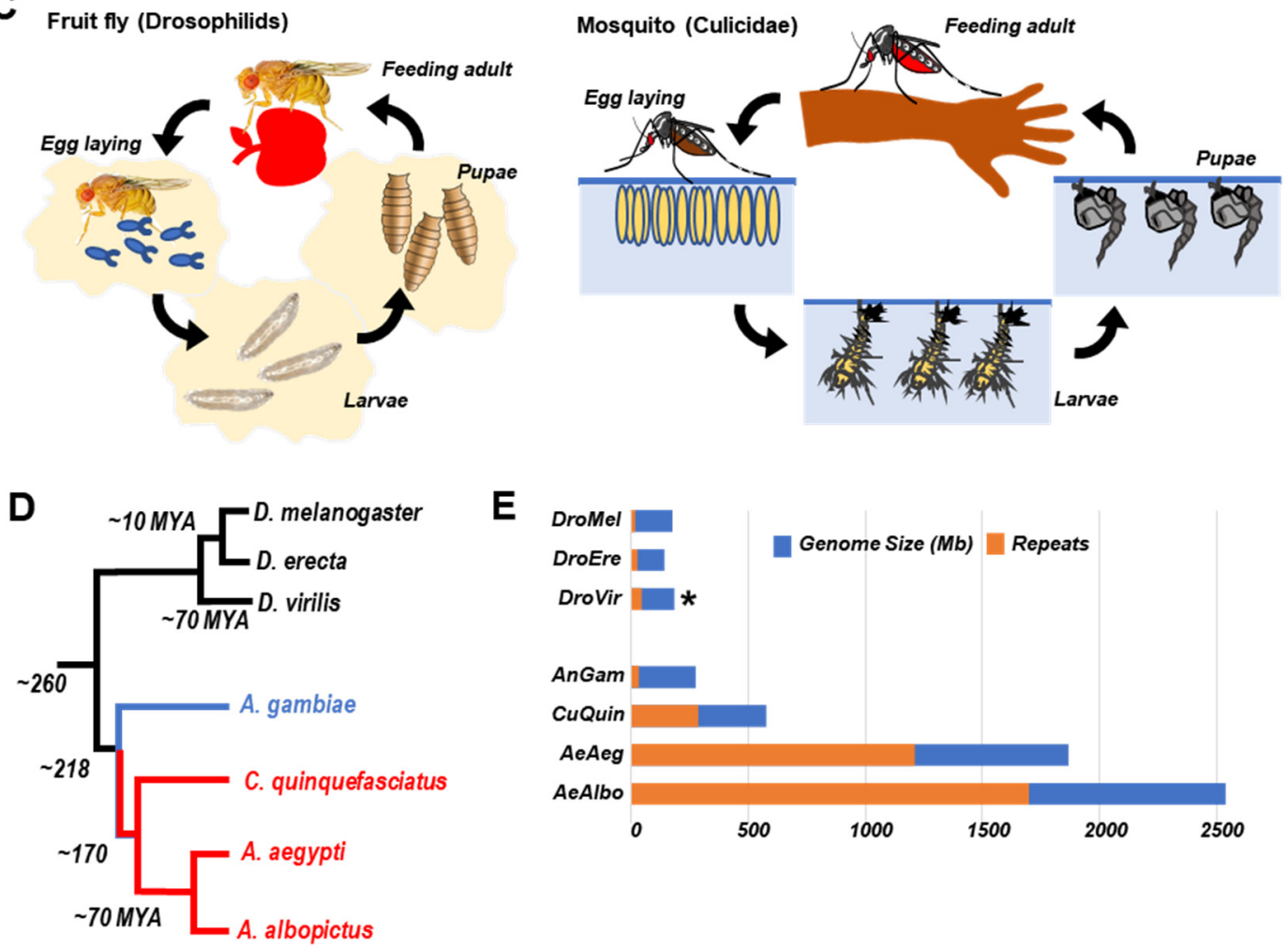

E

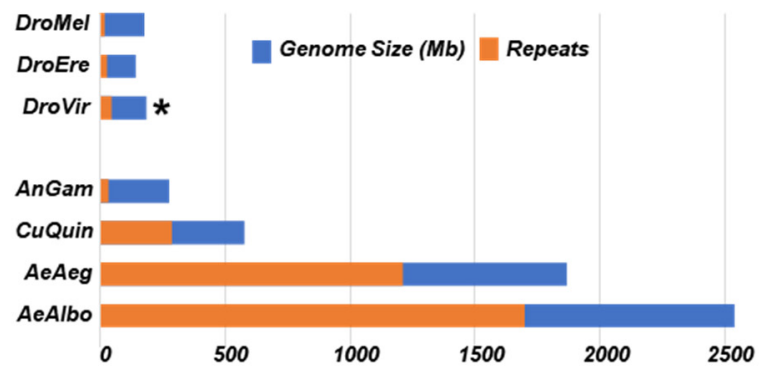

Figure 1. Comparing small RNA pathways between fruit flies (Drosophilids) versus mosquitoes (Culicids). (A) Phylogeny of the Argonaute-(Ago) family proteins from Drosophila with diagrams of these Ago-small RNA complexes. (B) Size distribution graphs representing the Drosophilid and Culicid small RNA profiles of female animals not directly infected with arboviruses. D. melanogaster data from [47], whereas Ae. albopictus data is from [46]. (C) Biological and niche differences and life-cycle commonalities. (D) Evolutionary phylogeny of Drosophilids versus Culicids. (E) Genome size and repetitive sequence composition differences based on current NCBI/Genbank genome assemblies and annotations of these Dipteran species. The asterisk notes that the current assemblies of the $D$. virilis genome are smaller than the actual genome because of sizeable satellite DNA absent from the reference assemblies [48].

\section{Genomic, Physiological and Evolutionary Differences between Drosophilids and Mosquitoes}

To understand the biological context of the different small RNA class profiles between these two Dipterans, we first briefly review the physiological differences and similarities between these two insect 
clades. Fruit flies and mosquitoes share four similar life cycle stages, beginning with females laying fertilized eggs that hatch as larvae, the larvae undergo four instar stages and then enter a pupal stage to undergo metamorphosis, then eclose as adults (Figure 1C). Whereas both clades are cosmopolitan insects, their ecological niches and feeding physiologies are completely distinct. Fruit fly females can reproduce and the larvae thrive on the nutrients of rotting fruit, whereas female adult mosquitoes require a blood meal to develop her eggs which are oviposited in standing water for the larvae to hatch and develop in this completely aqueous environment.

Although 260 million years (MY) of evolution has separated the Culicidae from Drosophila with distinct physiology and ecology (Figure 1D), the diversity within Drosophilids is narrower than Culicids, with most Drosophilids being related to each other within $\sim 70 \mathrm{MY}$ at the whole genome comparison scale that may also mirror the clade's more narrow ecological niches $[49,50]$. In contrast, the two most prolific and biomedically important Aedes species, Aedes aegypti (Ae. aegypti) and Aedes albopictus (Ae. albopictus) are diverged by $\sim 70 \mathrm{MY}$ of evolution at the whole genome scale, followed by another $\sim 100$ MY separating the Culex lineage (Figure 1D) [51,52]. Finally, mosquitoes can be further divided into two major subclades that have $\sim 48 \mathrm{MY}$ of evolutionary separation: the culicine subclade that encompasses Culex and Aedes species, and the anophiline subclade with Anopheles gambiae (An. gambiae) as the representative species because of its widespread proliferation in tropical climates and the primary vector of malaria.

The subclade distinctions between anopheline and culicine mosquitoes not only reflect broader geographical preferences but also reflects two prominent biological and genomic characteristics. Only a small handful of arboviruses have been identified to be vectored by anopheline mosquitoes, ONNV and Mayaro virus $[53,54]$, whereas culicine mosquitoes are infamous for their prolific capacity to vector EEEV and WNV in Culex strains and Chinkungunya virus, Yellow Fever virus, Zika virus, and dengue virus in Aedes strains [55-59]. Coincidently, the genome sizes and repetitive element contents of culicine mosquitoes is a magnitude larger than an anopheline mosquito genome and Drosophilid genomes (Figure 1E). In fact, Drosophilid and anopheline genomes are more related to each other through their compactness and minor fraction $(<20 \%)$ of repetitive elements as well as generally limited proliferation of insect-specific viruses amongst Drosophilids [60].

\section{Genome Transposon Composition and Germline Specificity of piRNAs in Drosophilids and Mosquitoes}

Before we compare the endogenous piRNA clusters between Drosophilids and Culicids, we first review how genomic transposon content varies between Drosophilid, anopheline, and culicine lineages (Figure 1E). With its well-curated compact genome and $~ 140$ manually annotated transposon families [61,62], Drosophila is the quintessential basis for dipteran comparisons. Despite some variations in estimates of transposon content across Drosophilid genomes [62-64], the relative abundance of transposons is conserved $[62,65]$ and piRNA abundance correlates well with transposon load $[66,67]$.

In contrast to fruit flies, culicine mosquitoes exhibit more drastic differences including larger genomes and extensive numbers of transposon families (Figure 1E) [68-71]. Interestingly, the transposon fractional proportion is similar between An. gambiae and Drosophilids genomes, perhaps also reflecting their similarly compact genome sizes. Among the large genome sizes of culicine mosquitoes [70,72], Ae. albopictus outranks Culex quinquefasciatus (Cu. quinquefasciatus) and Ae. aegypti having the greatest proportion of transposons relative to its genome (Figure 1E) [71,73]. Thus, mosquitoes represent a unique opportunity to investigate the relationship between expanding genomes, transposons, and their diverse defenses among closely and distantly related Dipteran species.

Among the many diverse defenses against transposons in insects, the piRNA pathway is a widely conserved mechanism to suppress the transposons which pose a perpetual threat to genome integrity [43,74-76]. Both Drosophilids and mosquitoes have the capacity to express piRNAs, but the pathway is best understood in Drosophila melanogaster (D. melanogaster). To discuss how Drosophilids piRNA pathways differ from mosquitoes, we highlight Drosophila-specific features. For example, 
the majority of Drosophila transposon-derived piRNAs are produced in the female germline [77] with a minor specialized somatic piRNA pathway in the follicle cells of the ovary [78] and in the fat body [79] (Figure 2A). In females, somatic piRNA cluster expression is lower than those present in the germline [80] (Figure 1B).

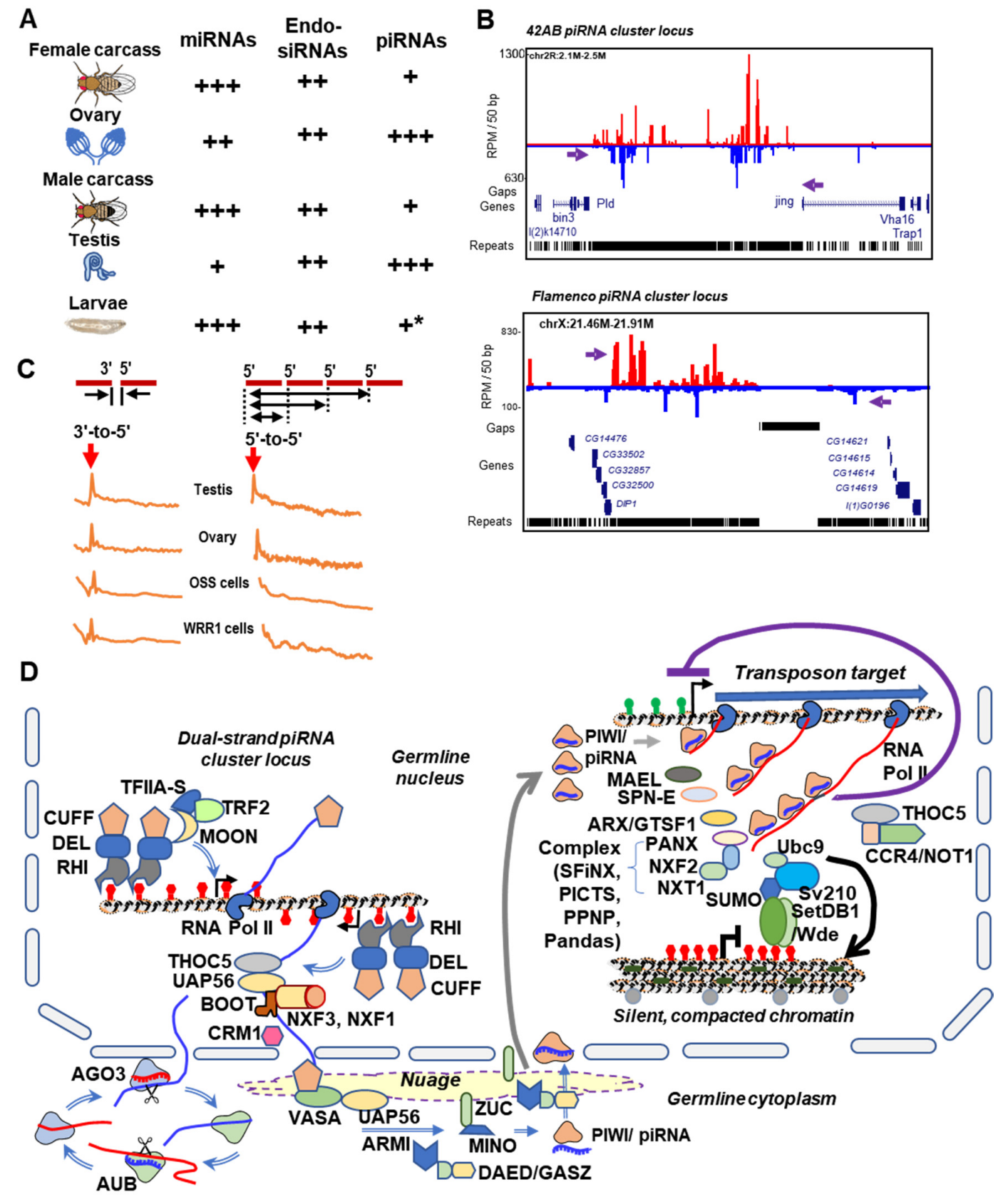

Figure 2. Drosophila-focused Piwi/piRNA pathway features. (A) Drosophila piRNA expression is restricted to germline, with an asterisk for piRNAs in larvae libraries that include the larval gonads. (B) Configuration of two notable Drosophila piRNA cluster loci, $42 A B$ and flamenco. (C) Drosophila piRNA phasing patterns analyses with red arrows pointing to salient signature of piRNAs juxtaposed to each other from the precursor transcript. (D) Schematic of Drosophila-specific Piwi/piRNA pathway silencing complexes such as the Rhino-Deadlock-Cutoff complex that promotes piRNA biogenesis from the 42AB locus (left) and a transcriptional gene silencing network (right; various names like SFiNX, PICTS, PNPP, Pandas complex) and Sv210 and CCR4/NOT1 complex that target transposon silencing at the chromatin level in the nucleus. 
In contrast, male flies generally have reduced expression of piRNAs overall [77] and contain male-specific piRNA mapping patterns [81]. Such sex-specific differences suggest that multiple pathways for piRNA biogenesis may exist in fruit fly testes despite the limited role of piRNA-mediated silencing of transposons in the male [82]. The reasons for these differences in piRNAs and transposons between sexes remains unknown, but perhaps transposon silencing in the Drosophila male germline occurs in a narrow window because the Drosophila testes has fewer actively transcribing spermatogonia cells compared to the ovary where numerous large nurse cells and smaller follicle cells are actively dividing in the Drosophila egg chamber $[83,84]$. Nevertheless, there is still progress to further dissect Piwi pathways in Drosophilid spermatogonia such as possible nuclear to cytoplasmic shuttling of PIWI during spermatogonia mitosis [85]. Overall though, there are much fewer studies discussing piRNA biogenesis in the Drosophila male germline [86-90] compared to the female germline, which we predict may also be the trend in mosquitoes if spermatogenesis development patterns are similar.

The conventional wisdom is that transposon genomic load would positively correlate with greater expression of transposon-mapping piRNAs. However, culicine mosquitoes seem to challenge this notion considerably. For example, although $>65 \%$ of the Ae. aegypti genome is filled with transposons, a low proportion $(<5 \%)$ of piRNAs derived from these transposons [91]. In Ae. albopictus, the amount of transposon-mapping piRNAs are even less than Ae. aegypti despite an even larger genome with a greater fraction of repeats [92]. Interestingly, the female somatic tissues of $\mathrm{Cu}$. quinquefasciatus have higher expression of transposon-mapping piRNAs, a feature not present in fruit flies [46].

However, the transposon-mapping piRNAs in anopheline mosquitoes mirror Drosophila: transposons are just $\sim 15 \%$ genome size yet $>70 \%$ of detected piRNAs are produced from transposon-containing piRNA clusters [75]. Perhaps, the lack of transposon-derived piRNAs in culicine mosquitoes are permitting transposons to replicate in and result in the expansion of these genomes $[93,94]$. With anopheline features looking more like Drosophila than culicine features, this raises the question as to what evolutionary event sparked this stark difference in genome transposon loads and transposon-mapping piRNAs in the culicine mosquito lineage. From these genome transposon loads, we also speculate that the anopheline mosquitoes are more closely related to the last common mosquito ancestor than the culcine mosquitoes.

Perhaps the tremendous genomic expansion in the culicine mosquitoes and greater capacity to be more prolific viral vectors compared to anopheline mosquitoes causes a biological need for culicine mosquitoes to express piRNAs in all tissues. In stark contrast to anopheline and Drosophilids, the piRNAs in culicine mosquitoes are detected in both germline and somatic cells and have similar expression levels to miRNAs (Figure 3A) [46,95]. This unique characteristic of bountiful somatic piRNAs in culicine mosquitoes prompts the question of why piRNAs are so restricted to the germline in Drosophila? Although some Drosophila piRNAs have been suggested to regulate embryonic development by degrading maternally deposited transcripts in the zygote which has also now been observed in Ae. aegypti [96-99], more of the Ae. aegypti piRNAs have been mapped to protein-coding genes abundantly expressed in the soma $[100,101]$.

Ultimately, the transcriptional control of piRNA expression may be exceptionally narrow in Drosophila, as only four out of many tens of known Drosophila cell lines display robust piRNA expression (FGS, OSS/OSC, WRR1, Kc167) [102-106]. In contrast, every mosquito cell line we have analyzed expresses robust piRNAs [46] and many other lepidopteran insect cells also express abundant piRNAs [107-110]. In fact, the physiologically broader expression of piRNAs in mosquito somatic cells is a common trend in most other insect species [47]. 
A

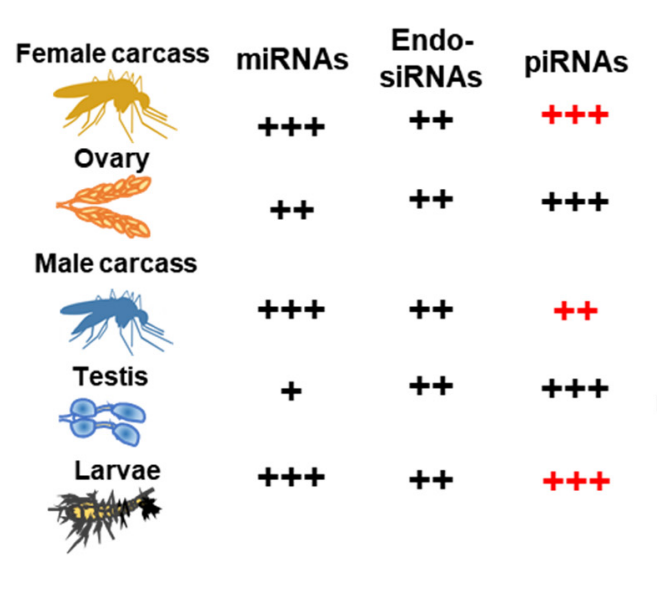

B

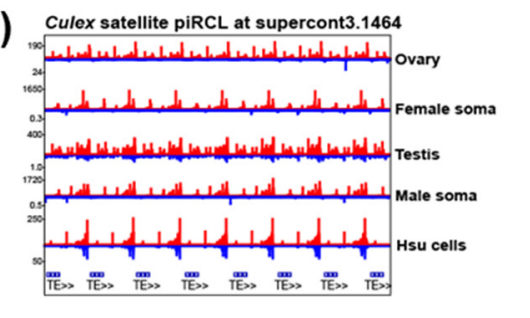

ii) Aedes albopictus satellite piRCL at NW_-021837267.1

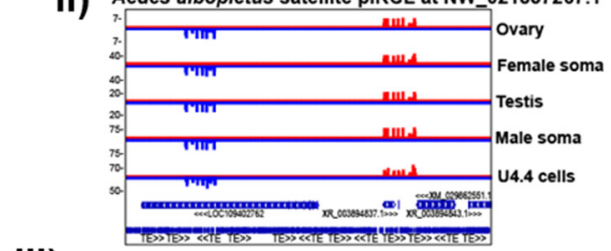

iii)

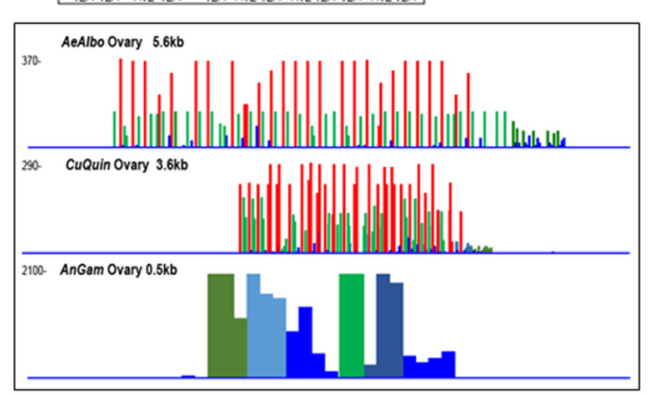

C
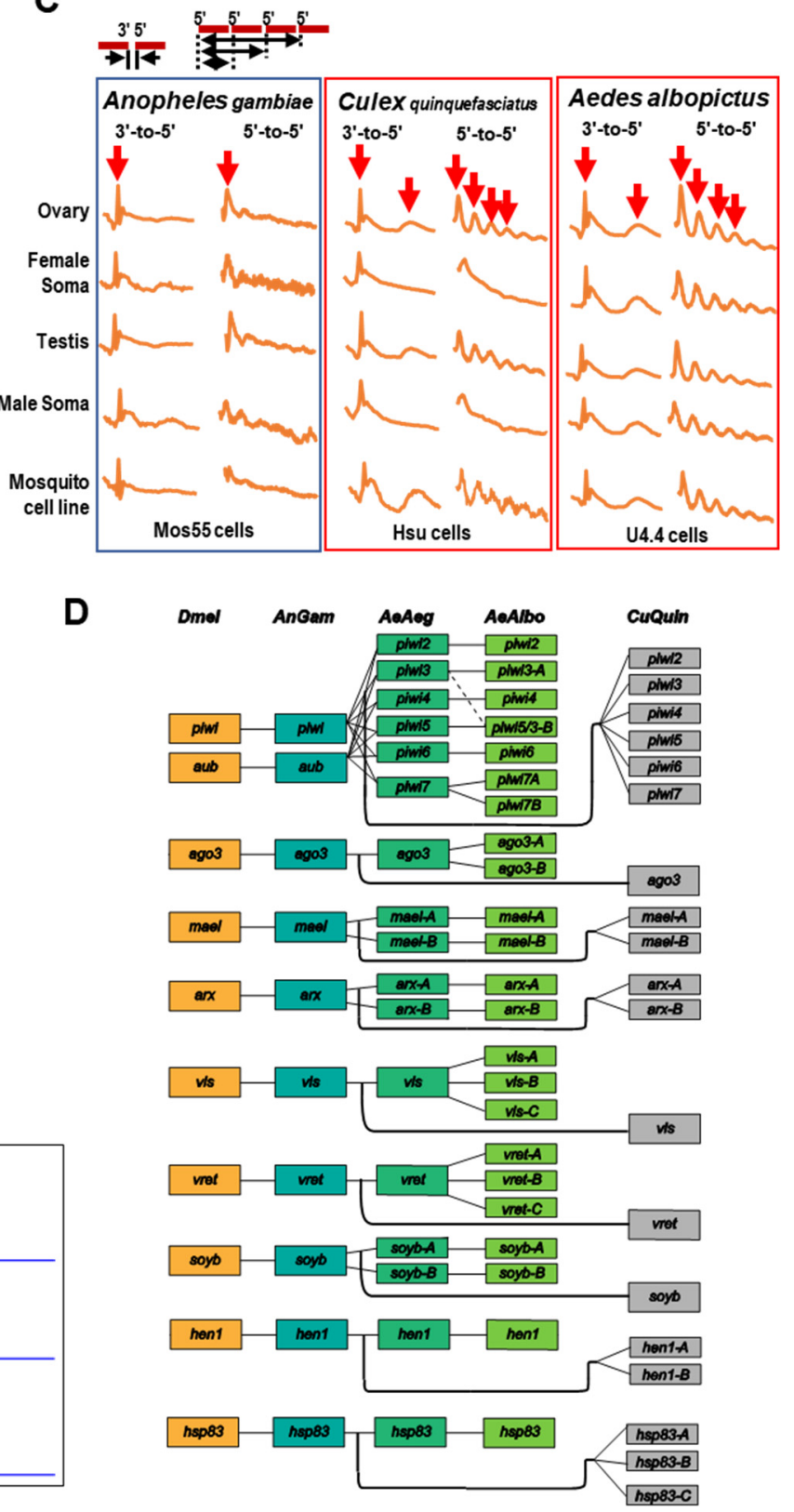

Figure 3. Mosquito-focused Piwi/piRNA pathway features. (A) Mosquito piRNA expression is notably broad and almost as ubiquitous as miRNAs in being expressed both in the soma and gonads. (B) Genome browser snapshots showing the novel configuration of piRNA cluster loci (piRCL) in culicine mosquitoes as satellite piRCLs, with (i) a Culex satellite piRCL, (ii) an Aedes satellite piRCL, and (iii) a deeply conserved piRCL that is a greatly expanded satellite repeat in culicine mosquitoes but is very compact in the anopheline species. (C) Mosquito piRNA phasing patterns analyses with red arrows pointing to salient signature of piRNAs juxtaposed to each other from the precursor transcript. The periodicity of piRNA phasing is most apparent in culicine mosquitoes. (D) Multiple Piwi pathway genes underwent homolog expansion amongst culicine mosquito lineages, most notably the expansion of PIWI homologs.

\section{The piRNA Clusters of Drosophila and Culicidae-Genomic Memory Bank of Transposon Invasion Versus Unique piRNA Clusters Containing Satellite DNA Repeats}

Drosophila has led the small RNA/transposon field with the original definition of piRNAs clusters as master control loci of transposons [111] by extending the terminology first coined by Nobel laureate 
Barbara McClintock [112-114]. Drosophila possess two related but distinct piRNA pathways in the ovary, a somatic component in the follicle cells and a germline component in the nurse cells [78,115-120], where different piRNA cluster loci are uniquely regulated, yet both have their distinct transposon remnants. In the nurse cells, the master control locus termed $42 A B$ cluster is a dual-stranded piRNA cluster that produces piRNAs from both DNA strands to target transposons in the germline [121] (Figure 2B). This cluster depends on a specialized set of proteins known as the rhino, deadlock, and cutoff (RDC) complex to process various piRNAs with sequence homology to various nested transposons $[67,122,123]$ (Figure 2D). Mutations in RDC components lead to major increases in various transposons, like HetA and Burdock [122,124-129].

In contrast to the $42 A B$ cluster expressed in nurse cells, the flamenco cluster [78] is only active in the follicle cells to generate a uni-strand piRNA cluster from an alternatively spliced transcript [130]. Before the field knew the flamenco locus was a piRNA cluster, it garnered its interesting name from being a regulator of the gypsy family of retrotransposons, which invade the germline exclusively through the somatic niche $[131,132]$. The constant repression of transposons in the germline likely results in the evolution of transposons (e.g., gypsy) that utilize enveloped viral particles to enter the germline $[133,134]$. Mutations in flamenco result in the loss of normal ovarian structure (via aberrant escort cells) due to the de-repression of transposons [135].

Like Drosophila, mosquito genomes also contain piRNA clusters (Figure 3B(i),B(ii)). However, mosquito piRNA clusters are particularly poorly understood compared to Drosophila. Earlier small RNA sequencing studies did first confirm the presence of piRNA clusters in Ae. aegypti [91], An. gambiae [136] and in Ae. albopictus [92], but the incomplete genomic assemblies and transposon annotations in some of these species hampered efforts for a comprehensive catalog of piRNA clusters. An individual species examination in Ae. aegypti discussed a mosquito piRNA cluster analogous to the Drosophila flamenco cluster [137], but we believe greater insight into mosquito piRNA cluster evolution is gained through multiple-species comparisons that include piRNAs from $\mathrm{Cu}$. quinquefasciatus $[46,96]$.

For example, cross-species piRNA cluster comparisons lead to the discovery of a conserved piRNA Cluster Locus (piRCL) composed of satellite DNA repeats in culicine mosquitoes [46,96]. Among the major anopheline and culicine mosquitoes, this piRCL is found near two genes of unknown function (Figure 3B(iii)) and did not appear to be restricted to any tissue or cell type [46]. Although these genes remain unknown, they serve as critical markers of genomic synteny enabling us to trace this piRCL's evolution across $170 \mathrm{MY}$ of mosquito evolution. Interestingly, this piRCL is conserved in An. gambiae but only as a compact piRNA cluster without tandem repeats that generates abundant piRNAs from the associated gene's $3^{\prime}$ UTR [46]. The anopheline piRCL may represent the ancestral mosquito compact locus that eventually expanded in culicine mosquitoes to include satellite DNA repeats in response to a new selective pressure on growing its genome size.

In terms of functionality, evidence suggests that this conserved piRNA cluster may be important for the maternal mRNA degradation pathway in mosquito zygotes and may be crucial for embryonic development in Ae. aegypti [96]. However, there is also evidence that this cluster is not exclusive to the early embryo and is found to be expressed in other tissues [46]. This finding puts forth the exciting possibility of this conserved piRCL having broader effects in other mosquito molecular processes (e.g., development and maintenance of germline). We also wonder if the innovation of culcine mosquitoes piRCLs composed mainly of satellite DNA repeats is linked to their capacity for expansive and repetitive genomes.

\section{Rapid Evolution of Piwi Genes and piRNA Pathways}

In response to transposons invading the soma and germline, Drosophilids have evolved distinct piRNA biogenesis mechanisms in each cell type. For example, somatically expressed single-strand clusters use canonical RNA Polymerase II transcription machinery to actively transcribe piRNA cluster transcripts $[138,139]$. In contrast, dual-strand clusters like $42 A B$ utilize other special proteins (RDC complex) in the female ovaries to promote piRNA cluster transcription (Figure 2D left) [122-125,128,140]. 
How and why the extraordinary divergence of piRNA biogenesis mechanisms arose still remains a mystery. Studies dissecting the complex protein interactions of the RDC complex suggest the role of adaptive evolution in shaping these distinct mechanisms [141,142].

piRNA-mediated silencing is predominantly associated with post-transcriptional silencing in the cytoplasm [30-35], however a single member of D. melanogaster PIWI does localize in the nucleus to direct transcriptional silencing through heterochromatin marks [143-146]. An extraordinarily complex relationship exists between the piRNA pathway and conserved heterochromatin-forming silencing complexes in Drosophila that continues to unveil new layers of regulation [145-150] (Figure 2D right). For example, very recent studies further uncovered the co-option of Mi-2, Rpd3, the Ccr4-Not complex, and the SUMO pathway with nuclear piRNA-guided transcriptional silencing $[146,151,152]$. Whether mosquito piRNA pathways can instigate chromatin silencing or utilize conserved heterochromatin formation machinery is still unknown.

Also unknown is whether mosquitoes contain distinct mosquito-specific piRNA biogenesis factors and silencing pathways for different cell types. However, we can suggest some insight from the evolution of Piwi gene members in mosquitoes. For instance, culicine mosquitoes showed an incredible expansion of the Piwi genes (up to seven orthologs) while anophelines retained a single Drosophila ortholog [46,153] (Figure 3D). Interestingly, both anophelines and culicine mosquitoes lack specific piRNA pathway genes (including $r h i, d e l$, and cuff among others) that are essential for dual-stranded cluster biogenesis in Drosophila $[46,124,147,149,150]$. Does this illustrate the lack of dual-stranded clusters in mosquitoes or hint to the possibility of a future discovery of unknown mosquito-specific proteins for piRNA biogenesis?

How the piRNA pathway evolved so rapidly between culicine and anopheline mosquitoes is a conundrum in the field. The presence of multiple Piwi genes may hint at selection developing protein/gene diversity against the evolution of transposons and viruses $[154,155]$. This is analogous to the expansion of APOBEC and KRAB-ZFN genes thought to be involved in arms races between eukaryotes and infections by retroviruses or retrotransposons [156-159]. Additionally, Piwi gene expansions could be a subfunctionalization response to the increased genomic complexity in culicine mosquitoes $[46,96]$. Perhaps during the genome expansion of Culicidae, Piwi genes were also expanded during the process and likely evolved culicids-specific mechanisms for piRNA biogenesis and silencing. Whatever the case, the evolution of culicine piRNA pathways have implications for transposon and virus defense of these efficient vectors.

\section{Culicine Mosquitoes Display Extraordinarily Phased piRNA Biogenesis Patterns}

Several other reviews have comprehensively covered the complex biogenesis mechanism of piRNAs that are clearly distinct from miRNA and siRNA biogenesis [34,43,118,160-162]. We summarize here the two key facets of piRNA biogenesis mechanisms that were first determined with Drosophila mutants and deep sequencing small RNA profiling $[29,35,163]$ in order to then highlight one extraordinary aspect of mosquito piRNA biogenesis [46].

One facet of piRNA biogenesis is the ping-pong mechanism where two separate Piwi proteins can bind either the top strand or bottom strand piRNA that are off-set in sequence complementarity by 10 bases, whereby the endonucleolytic "slicing" activity of one Piwi protein helps define the $5^{\prime}$ base of the piRNA bound by the complementary Piwi protein [164]. Like Drosophila, mosquitoes have an AGO3 Piwi protein that likely performs ping-pong with the PIWI and AUB orthologs in Drosophila [92,155,165,166]. However, other than the Tudor protein veneno [167], the other ping-pong partner definitions amongst the culicine mosquito 6 different PIWI orthologs are not yet well defined.

A second piRNA biogenesis facet is sequential, phased generation of piRNAs in a head-to-tail fashion via additional endonucleases such as zucchini, trimmer, and nibbler [109,164,168-170] and helicases like vasa and armitage [171-173]. This phased generation of piRNAs may be kicked off by an initial ping-pong event via a "Trigger" piRNA that then leads to subsequent production of "Responder" piRNAs. This phasing pattern is discerned by various signal processing algorithms that reflect the 
initial Responder piRNA closest to the Trigger piRNA as the most abundant signal and then rapid decay and dissolution of the phasing pattern beyond the next couple of trailing piRNAs $[164,168,174]$.

This phasing mechanism is deeply conserved across the animal kingdom, as shown by [164]. Notably, this study showed in the Ae. aegypti ovary that the $5^{\prime}$-to-5' piRNA phasing profile is smoothly periodic and extends $\sim>4$ piRNAs downstream of the initial peak. Most other animal's piRNA phasing patterns are not as striking as this Ae. aegypti pattern. In fact, this remarkably periodic phasing pattern was only seen in two other culicine mosquitoes, Ae. albopictus and $\mathrm{Cu}$. quinquefasciatus but absent in An. gambiae and Drosophilids [46] (Figure 3C). We do not yet understand how and why the $5^{\prime}$-to-5' piRNA phasing profile is so striking in culicine mosquitoes, but we note that this pattern is maintained in the mosquito cell cultures that may be amenable to functional genomics and biochemical studies of this feature.

\section{Viral piRNAs in Drosophila versus Mosquitoes: Minor in the Former and Major in the Latter?}

As described before, Drosophila piRNAs' main function is to silence transposons which can damage the germline genome $[34,43,118,161,175]$. However, a few studies suggests an antiviral immunity role for Drosophila viral piRNAs seen in the OSS cell line from mainly the plus strand of Drosophila C virus (DCV) and American Nodavirus (ANV), whereas other viruses like Noravirus, Drosophila B virus, and Drosophila X virus were generating viral siRNAs from both strands of the virus [176-178]. Although detection of viral piRNAs in intact Drosophila remains scant, two studies demonstrated increased replication of WNV and DXV replication after infecting piwi and spn-E mutants $[177,178]$. These studies are contrasted by Petit et al. who argue that the Piwi pathway is not required for antiviral responses in Drosophila where no SINV piRNA were detected because the AGO2/endo-siRNA pathways may provide the bulk of the antiviral responses [179].

Although the AGO2/endo-siRNAs also appear to silence transposons $[29,102,180-183]$ and provide antiviral immunity against viruses $[177,178,184-193]$, the interplay between antiviral and transposon silencing pathways remains elusive. However, a recent study in D. melanogaster and D. simulans demonstrated a significant decrease of transposon activity exclusively in the soma of SINV-infected flies [194]. In the same study, an impaired siRNA pathway led to the increased production of viral piRNAs, a possibly oversaturated piRNA machinery, and an increase in transposon transcripts, suggesting a tight synergy between both pathways [194]. An interesting implication is a complex genetic cross talk between the endo-siRNA antiviral response and transposon regulation by piRNAs in Drosophila, with an open question of whether a somatic role for piwi and spn-E and some Piwi components are underlying this genetic cross talk.

A fascinating aspect of mosquito vector biology is their ability to allow systemic and persistent viral infections with high viral loads. In mosquitoes, RNAi is widely known to be the predominant innate immune program against viruses [195]. However, the extent to which some or all of these small RNA pathways limit viral propagation is unknown. Recently, studies have shown the ability of both mosquitoes and cell lines to give rise to virus-derived viral piRNAs (vpiRNAs) upon virus infection $[46,76,153,155,165,167,196-199]$. Unlike mosquitoes, Drosophilids appear to lack viral piRNAs in their soma and germ cells despite viral infections (Figure 1B) [179]. This difference among Dipterans can be attributed to the capacity of mosquitoes to be prolific flavivirus vectors.

Indeed, isolated mosquito cell lines also maintain persistent viral infections despite being cultured away from the animal for decades. The ability to maintain low viral titers in specific infected-mosquito cell lines illustrates the effectiveness of the antiviral immune program [200-203]. Although the Ae. albopictus C6/36 cell line is unable to mount antiviral siRNAs due to a dcr-2 deficiency $[165,198]$, these cells are extremely useful for the propagation of viruses such as ZIKV [204,205]. To overcome the RNAi deficiency, C6/36 cells must be supplemented with synthetic siRNAs to reduce viral infection [206].

An interesting facet of vpiRNA production in culicine mosquitoes is how quickly they can produce vpiRNAs. Depending on the virus and medium (cell culture or mosquitoes), there is evidence suggesting piRNAs can be detected within a few days to 1 week $[46,196,207,208]$. For example, 
production of siRNAs in mosquito cells were prominent during the early stages of Rift Valley fever virus infection, whereas vpiRNAs significantly accumulated later on [208]. Similarly, in CHIKV-infected Ae. albopictus mosquitoes, vpiRNAs were detected in low levels at three days but became abundant after nine days [196]. Likewise, vpiRNAs in ZIKV-infected mosquitoes were detected within one week $[46,207]$. The differing results from these studies likely reflect the complexity of virus-mosquito interactions in vivo. More importantly, these results point to an underlying partnership between the siRNA and piRNA pathways for antiviral immunity in mosquitoes.

Viral DNA fragments have been found to be integrated into host genomes $[8,209,210]$. Whereas viral integrations are prevalent in Culicidae genomes, amazingly, Aedes mosquitoes have 10 times more EVEs than other mosquito species [211-214]. This striking capacity may reflect on the repetitive genomes of Ae. aegypti and Ae. albopictus. The highly repetitive genome of Ae. albopictus ranks higher in more EVEs (located outside piRNA clusters) compared to Ae. aegypti [215]. Despite being more similar in size and repeat content to D. melanogaster, An. gambiae genomes also have EVEs inside piRNA clusters [212,215], likely reflecting mosquito-specific evolution. The reason for these species-specific differences between having EVEs outside or inside piRNA clusters still remains a mystery. Further characterizations of EVEs across species will be required to further understand this evolutionary outcome.

Recently, a unique piRNA cluster was discovered in Ae. aegypti mosquitoes that resembled $D$. melanogaster's flamenco locus [137]. This $143 \mathrm{~kb}$ "flamenco-like locus" is a single unidirectional cluster composed of several non-retroviral EVEs and transposons with the capacity to express both EVEand transposon-piRNAs. The lack of EVEs in Drosophila pose interesting questions about how EVEs eventually evolved to be maintained in this flamenco-like locus in Ae. aegypti. Whether this locus is conserved in other culicine species remains unknown. Furthermore, it is unclear if this locus plays a crucial role for antiviral immunity in mosquitoes. Perhaps it depends on viruses that cause persistent viral infections. Recent evidence suggests some non-retroviral EVEs in Ae. aegypti mosquitoes can provide antiviral immunity against cell fusing agent virus (CFAV), a widely circulating mosquito virus [216]. An interesting question is how highly repetitive genomes (e.g., culicine mosquitoes) maintain antiviral EVEs located in either inside or outside piRNA clusters.

\section{Is the Role of Active Transposons Causing Hybrid Fertility in Drosophila Conserved in Mosquitoes?}

In a classic genetic phenomenon of hybrid sterility, pioneering studies in Drosophila have made important associations of this phenotype to transposon control by piRNAs [217-220]. The P-element transposon is one prominent agent driving the molecular basis of this phenomenon [2,221-226]. Female sterility occurs in F1 progeny from crosses between a P-element-containing male and a female lacking P-elements. In the reciprocal cross where the female possesses the P-elements, the F1 hybrids are fertile (due to maternal contribution of piRNAs [227]). The dysgenic cross where F1 females are sterile because the lack of P-element silencing is thought to cause defects like chromosomal breakage, germline cell apoptosis, and an increase in point mutations that harm female germ cell development [228].

The study of how Drosophila regulates P-element control is still an active and important topic. For example, P-elements have completely invaded nearly all wild Drosophila populations, but interplay between how quickly the piRNA pathway adapts to controlling P-element silencing is still being investigated [229-231]. An outstanding question is determining to what extent P-element copy number affects the severity of hybrid dysgenesis. Both recent and early studies demonstrated a positive correlation between hybrid dysgenesis severity and P-element copy number [2,3,225,232], however, others report a weak [233] or lack of correlation [234-236]. The discrepancy may be due to species-specific differences, intraspecies genetic differences, P-element structural variation, or piRNA cluster size [234,237-239].

Could fertility studies in mosquito hybrids gain insight from Drosophila P-element hybrid dysgenesis studies? We are still at the early stages of determining the underlying genetic mechanisms behind how 
some crosses are sterile whereas other crosses from the same set of species but of different geographical regions can become fertile. For example, in Hawaii, nonviable eggs were produced in mating between Ae. albopictus females and Ae. aegypti males, but in reciprocal mating, hybrids were produced [240]. However, when similar crosses were performed on Florida strains, no hybrids were produced [241]. Could it be possible that a mosquito's unique repertoire of transposon-derived or viral-derived piRNAs contribute to this phenomenon? A survey of mosquito strains around the world may give insights into this question.

We propose that studying piRNA pathways and transposon regulation factors could lead to new insights in earlier studies of hybrid sterility in mosquitoes. Examples of hybrid sterility studies are from An. gambiae sterile hybrids [242] that suggest an unidentified incompatibility factors on the X chromosome [243-245], and meiotic abnormalities from the unpairing of sex chromosomes [243]. In addition, early work in Anopheles arabiensis hybrids discovered a transposon named Odysseus present at the junction of an inversion, with distinct distributions of this element in different strains [246]. The role of inversions in adaptation and speciation in the An. gambiae complex have been extensively studied and reviewed in [247]. Could there be a link between anopheline hybrid incompatibilities and transposons, with the possibility of piRNAs modulating this phenomenon? We also speculate if hybrid sterility in mosquitoes could be linked to the different compositions of piRNAs coming from virus and endogenous viral elements (EVEs).

\section{How Conserved is the AGO2 Endo-siRNA Pathway between Drosophila and Mosquitoes?}

In Drosophila, endogenous siRNAs (endo-siRNAs) were first defined as being a distinct class from the 'repeat-associated siRNAs' [248-252] that were later classified as piRNAs [67,120,253]. Although one study described endo-siRNAs in both the germline and soma tissues with no unique differences in biogenesis [254], the main distinction of endo-siRNAs from piRNAs in Drosophila is a broader role for siRNAs in the soma toward antiviral defense [186], transposon defense [255], and gene regulation [256] (Figure 2A). In contrast to exogenous siRNAs, endo-siRNAs are derived from the genome itself rather than an exogenous source such as viruses and use distinct biogenesis pathways [257]. With the slicing role of AGO2 being crucial for all siRNA pathways [182,186,255,258,259], fruit flies utilize AGO2 for both exo- and endo-siRNA pathways, suggesting co-evolution of two distinct small RNA pathways [31].

In mosquitoes, little is known about the endo-siRNA pathway and few studies document the presence of siRNAs. The role of endo-siRNAs in antiviral immunity [260] and transposon defense in the gonads [261] demonstrates the versatility of this pathway in defense mechanisms. Interestingly, the majority of mosquito siRNA studies point to the exo-siRNA pathway as a major process against viral infection [200,262-267]. Why the exo-siRNA pathway has a dominant role in antiviral immunity is unknown. Insight into the host-virus evolution may explain why the endo-siRNA pathway has a smaller role against viruses. For example, the mosquito exo-siRNA pathway genes appear to undergo rapid, positive, and diversifying selection $[268,269]$.

Since mosquitoes are prominent vectors for viruses compared to Drosophilids, it is likely that an evolutionary arms race between mosquitoes and viruses is compelled to diversify the siRNA pathway against the virus or associated viral suppressors of RNAi. These viral counter-defenses drive adaptations in the host immune genes and can ultimately lead to highly specific host and virus interactions (e.g., the exo-siRNA pathway) [270]. Future comparative studies on the evolution of siRNA pathways between fruit flies and mosquitoes will provide valuable insights into the species-specific adaptations against viruses.

\section{RNAi Pathways as Applications for Mosquito Vector Control}

There are practical applications to understanding the piRNA pathway in mosquitoes such as the development of novel tools and approaches for mosquito vector control. For example, scientists leveraged their understanding of the miRNA pathway in mosquitoes to build synthetic miRNAs in 
transgenic Ae. aegypti to target RNA arboviruses such as ZIKV, CHIKV, and DENV [205,271]. Another report also developed transgenic Ae. aegypti mosquitoes that robustly expressed inverted-repeat sequences derived from the DENV-2 genomic RNA to trigger the RNAi response and confer significant resistance to this virus [272]. The development of these tools against flaviviruses are especially important for the field of vector control because traditional tools such as insecticides are increasingly becoming inefficient due to mosquitoes acquiring insecticide resistance [273].

Novel genetic tools are becoming a promising alternative to curb the spread of harmful mosquito-borne pathogens. A question still remains: can piRNAs be used for targeting RNA viruses in transgenic mosquitoes and be as efficient as similar strategies mentioned above? Rapid advances in gene editing of mosquitoes and mosquito cell cultures will be the key towards harnessing mosquito small RNA biological pathways so that one day we can tame and domesticate these diverse Dipteran defenses to serve humankind.

\section{Final Thoughts: Strengthening the Fly-Mosquito Partnership for Future Biomedical Progress}

Many fundamental molecular and developmental biology discoveries, including the Piwi pathway were first made in Drosophila [274-276] due in part to its simple husbandry, compact genome size and pioneering genetic tools. Mosquito researchers can be envious of Drosophila's genetic tools, such as unparalleled annotation and manipulation of its genome [277], plethora of genetic markers and balancer chromosomes, and binary transgenes to trigger RNAi and CRISPR genome editing [278,279]. We envision that more and more investigators like in the Akbari and Lau labs [234,280-283] and other notable Drosophilists [284,285] will leverage their initial foundation of studies in Drosophila and extend their expertise to the mosquitoes.

Although mosquitoes have more complicated rearing protocols compared to Drosophila (e.g., larval development in water, adult rearing in cages, blood for production of eggs, humidity and temperature requirements), these organisms are rising as future models for studying insect development and molecular studies. With some advantages like Aedes embryos undergoing diapause as a useful storage trick in experiments [286], and being closely related to Drosophilids, we hope that future genomic comparisons and greater development of useful genetic tools in mosquitoes [287-290] will encourage more funding efforts and investigators supporting mosquito research.

Indeed, more work is required for both insects to illuminate the biology of small RNA pathways, but progress lags in mosquitoes because the field still needs better curated mosquito genomes. Currently, mosquitoes lack well annotated genomes and contain an astonishing number of repeats which ultimately makes genome annotation and sequence assembly more challenging. Some recent progress has been made to further improve Ae. albopictus' highly repetitive genome sequence [73] and to uncover its developmental transcriptome [291]. In addition, efforts to improve the Ae. aegypti [51] and An. stephensi [292] genomes were also accomplished.

The field would also benefit from a sampling of wild mosquito genomes from all over the world. The use of lab strains has advantages, but ultimately, wild mosquitoes are valuable resources to understand how mosquito genomes differ based on location and to understand if local exposure of particular pathogens can drive the evolution of small RNA pathways in distinct ways. For example, our study [46] detected differences in Ae. aegypti small RNA profiles and different loads of viral piRNAs between various lab strains versus other strains more recently isolated from the wild, but we do not know how variable are the underlying genomic piRCL sequences. In addition, recent studies in Drosophila showed ongoing transposon invasions and environmentally induced changes continuing to drive piRNA cluster evolution $[139,293]$.

An open question is why are somatic piRNAs prolific in Culicidae but largely absent in Drosophilids. Is it possible to ectopically express somatic piRNAs in Drosophila? Are there specific Drosophila factors/genes that prohibit somatic piRNAs and limit fruit flies from efficiently vectoring viruses? Perhaps the capacity of horizontal gene transfer modes between Drosophilids may be an explanation. Fruit flies consume fruit and fungi while female mosquitoes feed on sugar and blood to obtain necessary 
nutrients for egg production. Mosquitoes acquire infection by obtaining viral pathogens from animal blood. Could blood feeding be a route for horizontal gene transfer if midgut digestion is not thoroughly complete? Further characterization of wild insect lines may shed some light on this matter.

There is a need to apply genetics and functional genomics in the mosquito to better understand the small RNA pathway features. New genetic tools for mosquitoes are still emerging, such as germline editing using CRISPR in mosquitoes [288,289] and novel Cas9 delivery via ReMOT [294-296] that may enable creating Piwi pathway mosquito mutants. These mutants could inform on whether infertility results from loss of mosquito Piwi genes, but the redundancy of Piwi genes in mosquitoes may also obscure an overt phenotype. Some groups are also leveraging CRISPR and RNAi in mosquito cell cultures for knock-out and knockdown studies of small RNA pathway genes to study viral infection responses [46,76,197,216,297-299], and we anticipate that future genome-wide intervention resources for mosquito will be developed when the mosquito genomic curations and annotations improve to the levels existing for Drosophila.

Funding: This research was funded by NIH grants R01-AG052465 and R01-GM135215 to NCL and Defense Advanced Research Project Agency (DARPA) Safe Genes Program Grant (HR0011-17-2- 0047) and an NIH New Innovator Award (1DP2AI152071-01) to OSA.

Acknowledgments: We apologize for any citations that were omitted due to inadvertent oversight and the specific focus in this perspective. SG dedicates this manuscript to the memory of her father, Armando Gamez Escareño, whose toil and sacrifice allowed his children to grasp the American Dream.

Conflicts of Interest: The authors declare no conflict of interest.

\section{References}

1. Karess, R.E.; Rubin, G.M. Analysis of P transposable element functions in drosophila. Cell 1984, 38, $135-146$. [CrossRef]

2. Bingham, P.M.; Kidwell, M.G.; Rubin, G.M. The molecular basis of P-M hybrid dysgenesis: The role of the P element, a P-strain-specific transposon family. Cell 1982, 29, 995-1004. [CrossRef]

3. Kidwell, M.G. Hybrid Dysgenesis in DROSOPHILA MELANOGASTER: Nature and Inheritance of P Element Regulation. Genetics 1985, 111, 337-350.

4. Conway, M.J.; Colpitts, T.M.; Fikrig, E. Role of the Vector in Arbovirus Transmission. Annu. Rev. Virol. 2014, 1,71-88. [CrossRef] [PubMed]

5. Lequime, S.; Lambrechts, L. Vertical transmission of arboviruses in mosquitoes: A historical perspective. Infect. Genet. Evol. 2014, 28, 681-690. [CrossRef] [PubMed]

6. Akkouche, A.; Rebollo, R.; Burlet, N.; Esnault, C.; Martinez, S.; Viginier, B.; Terzian, C.; Vieira, C.; Fablet, M. Tirant, a newly discovered active endogenous retrovirus in Drosophila simulans. J. Virol. 2012, 86, 3675-3681. [CrossRef]

7. Dolei, A. Endogenous retroviruses and human disease. Expert Rev. Clin. Immunol. 2006, 2, $149-167$. [CrossRef]

8. Feschotte, C.; Gilbert, C. Endogenous viruses: Insights into viral evolution and impact on host biology. Nat. Rev. Genet. 2012, 13, 283-296. [CrossRef]

9. Malik, H.S.; Henikoff, S.; Eickbush, T.H. Poised for contagion: Evolutionary origins of the infectious abilities of invertebrate retroviruses. Genome Res. 2000, 10, 1307-1318. [CrossRef]

10. Koonin, E.V.; Makarova, K.S.; Wolf, Y.I.; Krupovic, M. Evolutionary entanglement of mobile genetic elements and host defence systems: Guns for hire. Nat. Rev. Genet. 2020, 21, 119-131. [CrossRef]

11. Johnson, W.E. Origins and evolutionary consequences of ancient endogenous retroviruses. Nat. Rev. Microbiol. 2019, 17, 355-370. [CrossRef] [PubMed]

12. Obbard, D.J.; Gordon, K.H.J.; Buck, A.H.; Jiggins, F.M. The evolution of RNAi as a defence against viruses and transposable elements. Philos. Trans. R. Soc. Lond. B Biol. Sci. 2009, 364, 99-115. [CrossRef] [PubMed]

13. Aravin, A.A.; Hannon, G.J.; Brennecke, J. The Piwi-piRNA pathway provides an adaptive defense in the transposon arms race. Science 2007, 318, 761-764. [CrossRef]

14. Gammon, D.B.; Mello, C.C. RNA interference-mediated antiviral defense in insects. Curr. Opin. Insect Sci. 2015, 8, 111-120. [CrossRef] [PubMed] 
15. Qi, Y.; Hannon, G.J. Uncovering RNAi mechanisms in plants: Biochemistry enters the foray. FEBS Lett. 2005, 579, 5899-5903. [CrossRef] [PubMed]

16. Chiu, Y.-L.; Rana, T.M. RNAi in human cells: Basic structural and functional features of small interfering RNA. Mol. Cell 2002, 10, 549-561. [CrossRef]

17. Tijsterman, M.; Plasterk, R.H.A. Dicers at RISC; the mechanism of RNAi. Cell 2004, 117, 1-3. [CrossRef]

18. Li, X.; Wang, X.; Cheng, Z.; Zhu, Q. AGO2 and its partners: A silencing complex, a chromatin modulator, and new features. Crit. Rev. Biochem. Mol. Biol. 2020, 55, 33-53. [CrossRef]

19. Chawla, G.; Luhur, A.; Sokol, N. Analysis of MicroRNA Function in Drosophila. Methods Mol. Biol. 2016, 1478, 79-94. [CrossRef]

20. Asgari, S. Role of microRNAs in arbovirus/vector interactions. Viruses 2014, 6, 3514-3534. [CrossRef]

21. Dubey, S.K.; Shrinet, J.; Jain, J.; Ali, S.; Sunil, S. Aedes aegypti microRNA miR-2b regulates ubiquitin-related modifier to control chikungunya virus replication. Sci. Rep. 2017, 7, 17666. [CrossRef] [PubMed]

22. Avila-Bonilla, R.G.; Yocupicio-Monroy, M.; Marchat, L.A.; Pérez-Ishiwara, D.G.; Cerecedo-Mercado, D.A.; Del Ángel, R.M.; Salas-Benito, J.S. miR-927 has pro-viral effects during acute and persistent infection with dengue virus type 2 in C6/36 mosquito cells. J. Gen. Virol. 2020. [CrossRef] [PubMed]

23. Dubey, S.K.; Shrinet, J.; Sunil, S. Aedes aegypti microRNA, miR-2944b-5p interacts with $3^{\prime}$ UTR of chikungunya virus and cellular target vps-13 to regulate viral replication. PLoS Negl. Trop. Dis. 2019, 13, e0007429. [CrossRef] [PubMed]

24. Hussain, M.; Asgari, S. MicroRNA-like viral small RNA from Dengue virus 2 autoregulates its replication in mosquito cells. Proc. Natl. Acad. Sci. USA 2014, 111, 2746-2751. [CrossRef] [PubMed]

25. Skalsky, R.L.; Olson, K.E.; Blair, C.D.; Garcia-Blanco, M.A.; Cullen, B.R. A “microRNA-like” small RNA expressed by Dengue virus? Proc. Natl. Acad. Sci. USA 2014, 111, E2359. [CrossRef] [PubMed]

26. Finol, E. Are viral small RNA regulating Dengue virus replication beyond serotype 2? Proc. Natl. Acad. Sci. USA 2014, 111, E2915-E2916. [CrossRef]

27. Feng, X.; Zhou, S.; Wang, J.; Hu, W. microRNA profiles and functions in mosquitoes. PLoS Negl. Trop. Dis. 2018, 12, e0006463. [CrossRef]

28. Kritikou, E. Endo-siRNAs truly endogenous. Nat. Rev. Mol. Cell Boil. 2008, 9, 427. [CrossRef]

29. Okamura, K.; Lai, E.C. Endogenous small interfering RNAs in animals. Nat. Rev. Mol. Cell Boil. 2008, 9, 673-678. [CrossRef]

30. Golden, D.E.; Gerbasi, V.R.; Sontheimer, E.J. An inside job for siRNAs. Mol. Cell 2008, 31, 309-312. [CrossRef]

31. Claycomb, J.M. Ancient endo-siRNA pathways reveal new tricks. Curr. Biol. 2014, 24, R703-R715. [CrossRef] [PubMed]

32. Lucas, K.J.; Myles, K.M.; Raikhel, A.S. Small RNAs: A new frontier in mosquito biology. Trends Parasitol. 2013, 29, 295-303. [CrossRef] [PubMed]

33. Bamezai, S.; Rawat, V.P.S.; Buske, C. Concise Review: The Piwi-piRNA Axis: Pivotal beyond Transposon Silencing. Stem Cells 2012, 30, 2603-2611. [CrossRef] [PubMed]

34. Czech, B.; Munafò, M.; Ciabrelli, F.; Eastwood, E.L.; Fabry, M.H.; Kneuss, E.; Hannon, G.J. piRNA-Guided Genome Defense: From Biogenesis to Silencing. Annu. Rev. Genet. 2018, 52, 131-157. [CrossRef] [PubMed]

35. Huang, X.; Fejes Tóth, K.; Aravin, A.A. piRNA Biogenesis in Drosophila melanogaster. Trends Genet. 2017, 33, 882-894. [CrossRef]

36. Czech, B.; Hannon, G.J. One Loop to Rule Them All: The Ping-Pong Cycle and piRNA-Guided Silencing. Trends Biochem. Sci. 2016, 41, 324-337. [CrossRef]

37. Varjak, M.; Leggewie, M.; Schnettler, E. The antiviral piRNA response in mosquitoes? J. Gen. Virol. 2018, 99, 1551-1562. [CrossRef]

38. Schraivogel, D.; Meister, G. Import routes and nuclear functions of Argonaute and other small RNA-silencing proteins. Trends Biochem. Sci. 2014, 39, 420-431. [CrossRef]

39. Okamura, K. Diversity of animal small RNA pathways and their biological utility. Wiley Interdiscip. Rev. RNA 2012, 3, 351-368. [CrossRef]

40. Axtell, M.J.; Westholm, J.O.; Lai, E.C. Vive la différence: Biogenesis and evolution of microRNAs in plants and animals. Genome Biol. 2011, 12, 221. [CrossRef]

41. Clark, J.P.; Lau, N.C. Piwi Proteins and piRNAs step onto the systems biology stage. Adv. Exp. Med. Biol. 2014, 825, 159-197. [CrossRef] [PubMed] 
42. Parhad, S.S.; Theurkauf, W.E. Rapid evolution and conserved function of the piRNA pathway. Open Biol. 2019, 9, 180181. [CrossRef] [PubMed]

43. Ozata, D.M.; Gainetdinov, I.; Zoch, A.; O'Carroll, D.; Zamore, P.D. PIWI-interacting RNAs: Small RNAs with big functions. Nat. Rev. Genet. 2019, 20, 89-108. [CrossRef] [PubMed]

44. Iwasaki, Y.W.; Siomi, M.C.; Siomi, H. PIWI-Interacting RNA: Its Biogenesis and Functions. Annu. Rev. Biochem. 2015, 84, 405-433. [CrossRef] [PubMed]

45. Ambros, V.; Bartel, B.; Bartel, D.P.; Burge, C.B.; Carrington, J.C.; Chen, X.; Dreyfuss, G.; Eddy, S.R.; Griffiths-Jones, S.; Marshall, M.; et al. A uniform system for microRNA annotation. RNA 2003, 9, $277-279$. [CrossRef] [PubMed]

46. Ma, Q.; Srivastav, S.P.; Gamez, S.; Feitosa-Suntheimer, F.; Patterson, E.I.; Johnson, R.M.; Matson, E.R.; Gold, A.S.; Brackney, D.E.; Connor, J.H.; et al. An integrated mosquito small RNA genomics resource reveals dynamic evolution and host responses to viruses and transposons. bioRxiv 2020. [CrossRef]

47. Lewis, S.H.; Quarles, K.A.; Yang, Y.; Tanguy, M.; Frézal, L.; Smith, S.A.; Sharma, P.P.; Cordaux, R.; Gilbert, C.; Giraud, I.; et al. Pan-arthropod analysis reveals somatic piRNAs as an ancestral defence against transposable elements. Nat. Ecol. Evol. 2018, 2, 174-181. [CrossRef]

48. Flynn, J.M.; Long, M.; Wing, R.A.; Clark, A.G. Evolutionary Dynamics of Abundant 7-bp Satellites in the Genome of Drosophila virilis. Mol. Biol. Evol. 2020, 37, 1362-1375. [CrossRef]

49. Stark, A.; Lin, M.F.; Kheradpour, P.; Pedersen, J.S.; Parts, L.; Carlson, J.W.; Crosby, M.A.; Rasmussen, M.D.; Roy, S.; Deoras, A.N.; et al. Discovery of functional elements in 12 Drosophila genomes using evolutionary signatures. Nature 2007, 450, 219-232. [CrossRef]

50. Hahn, M.W.; Han, M.V.; Han, S.-G. Gene family evolution across 12 Drosophila genomes. PLoS Genet. 2007, 3, e197. [CrossRef]

51. Matthews, B.J.; Dudchenko, O.; Kingan, S.B.; Koren, S.; Antoshechkin, I.; Crawford, J.E.; Glassford, W.J.; Herre, M.; Redmond, S.N.; Rose, N.H.; et al. Improved reference genome of Aedes aegypti informs arbovirus vector control. Nature 2018, 563, 501-507. [CrossRef] [PubMed]

52. Dudchenko, O.; Batra, S.S.; Omer, A.D.; Nyquist, S.K.; Hoeger, M.; Durand, N.C.; Shamim, M.S.; Machol, I.; Lander, E.S.; Aiden, A.P.; et al. De novo assembly of the Aedes aegypti genome using Hi-C yields chromosome-length scaffolds. Science 2017, 356, 92-95. [CrossRef] [PubMed]

53. Carissimo, G.; Pain, A.; Belda, E.; Vernick, K.D. Highly focused transcriptional response of Anopheles coluzzii to O'nyong nyong arbovirus during the primary midgut infection. BMC Genom. 2018, 19, 526. [CrossRef] [PubMed]

54. Brustolin, M.; Pujhari, S.; Henderson, C.A.; Rasgon, J.L. Anopheles mosquitoes may drive invasion and transmission of Mayaro virus across geographically diverse regions. PLoS Negl. Trop. Dis. 2018, 12, e0006895. [CrossRef]

55. Sardelis, M. Vector Competence of Selected North American Culex and Coquillettidia Mosquitoes for West Nile Virus. Emerg. Infect. Dis. 2001, 7, 1018-1022. [CrossRef]

56. Bingham, A.M.; Burkett-Cadena, N.D.; Hassan, H.K.; Unnasch, T.R. Vector Competence and Capacity of Culex erraticus (Diptera: Culicidae) for Eastern Equine Encephalitis Virus in the Southeastern United States. J. Med. Entomol. 2016, 53, 473-476. [CrossRef]

57. Vega-Rúa, A.; Zouache, K.; Girod, R.; Failloux, A.-B.; Lourenço-de-Oliveira, R. High level of vector competence of Aedes aegypti and Aedes albopictus from ten American countries as a crucial factor in the spread of Chikungunya virus. J. Virol. 2014, 88, 6294-6306. [CrossRef]

58. McElroy, K.L.; Tsetsarkin, K.A.; Vanlandingham, D.L.; Higgs, S. Role of the yellow fever virus structural protein genes in viral dissemination from the Aedes aegypti mosquito midgut. J. Gen. Virol. 2006, 87, 2993-3001. [CrossRef]

59. Kotsakiozi, P.; Gloria-Soria, A.; Caccone, A.; Evans, B.; Schama, R.; Martins, A.J.; Powell, J.R. Tracking the return of Aedes aegypti to Brazil, the major vector of the dengue, chikungunya and Zika viruses. PLoS Negl. Trop. Dis. 2017, 11, e0005653. [CrossRef]

60. Zdobnov, E.M.; von Mering, C.; Letunic, I.; Torrents, D.; Suyama, M.; Copley, R.R.; Christophides, G.K.; Thomasova, D.; Holt, R.A.; Subramanian, G.M.; et al. Comparative genome and proteome analysis of Anopheles gambiae and Drosophila melanogaster. Science 2002, 298, 149-159. [CrossRef] 
61. Rahman, R.; Chirn, G.-W.; Kanodia, A.; Sytnikova, Y.A.; Brembs, B.; Bergman, C.M.; Lau, N.C. Unique transposon landscapes are pervasive across Drosophila melanogaster genomes. Nucleic Acids Res. 2015, 43, 10655-10672. [CrossRef] [PubMed]

62. Hill, T. Transposable element dynamics are consistent across the Drosophila phylogeny, despite drastically differing content. bioRxiv 2020. [CrossRef]

63. Drosophila 12 Genomes Consortium. Evolution of genes and genomes on the Drosophila phylogeny. Nature 2007, 450, 203-218. [CrossRef] [PubMed]

64. Flutre, T.; Duprat, E.; Feuillet, C.; Quesneville, H. Considering transposable element diversification in de novo annotation approaches. PLoS ONE 2011, 6, e16526. [CrossRef] [PubMed]

65. Kaminker, J.S.; Bergman, C.M.; Kronmiller, B.; Carlson, J.; Svirskas, R.; Patel, S.; Frise, E.; Wheeler, D.A.; Lewis, S.E.; Rubin, G.M.; et al. The transposable elements of the Drosophila melanogaster euchromatin: A genomics perspective. Genome Biol. 2002, 3, 1-20. [CrossRef] [PubMed]

66. Kelleher, E.S.; Barbash, D.A. Analysis of piRNA-mediated silencing of active TEs in Drosophila melanogaster suggests limits on the evolution of host genome defense. Mol. Biol. Evol. 2013, 30, 1816-1829. [CrossRef] [PubMed]

67. Brennecke, J.; Aravin, A.A.; Stark, A.; Dus, M.; Kellis, M.; Sachidanandam, R.; Hannon, G.J. Discrete small RNA-generating loci as master regulators of transposon activity in Drosophila. Cell 2007, 128, 1089-1103. [CrossRef]

68. Nene, V.; Wortman, J.R.; Lawson, D.; Haas, B.; Kodira, C.; Tu, Z.J.; Loftus, B.; Xi, Z.; Megy, K.; Grabherr, M.; et al. Genome sequence of Aedes aegypti, a major arbovirus vector. Science 2007, 316, 1718-1723. [CrossRef]

69. Neafsey, D.E.; Waterhouse, R.M.; Abai, M.R.; Aganezov, S.S.; Alekseyev, M.A.; Allen, J.E.; Amon, J.; Arcà, B.; Arensburger, P.; Artemov, G.; et al. Mosquito genomics. Highly evolvable malaria vectors: The genomes of 16 Anopheles mosquitoes. Science 2015, 347, 1258522. [CrossRef]

70. Arensburger, P.; Megy, K.; Waterhouse, R.M.; Abrudan, J.; Amedeo, P.; Antelo, B.; Bartholomay, L.; Bidwell, S.; Caler, E.; Camara, F.; et al. Sequencing of Culex quinquefasciatus establishes a platform for mosquito comparative genomics. Science 2010, 330, 86-88. [CrossRef]

71. Chen, X.-G.; Jiang, X.; Gu, J.; Xu, M.; Wu, Y.; Deng, Y.; Zhang, C.; Bonizzoni, M.; Dermauw, W.; Vontas, J.; et al. Genome sequence of the Asian Tiger mosquito, Aedes albopictus, reveals insights into its biology, genetics, and evolution. Proc. Natl. Acad. Sci. USA 2015, 112, E5907-E5915. [CrossRef] [PubMed]

72. Marsano, R.M.; Leronni, D.; D'Addabbo, P.; Viggiano, L.; Tarasco, E.; Caizzi, R. Mosquitoes LTR retrotransposons: A deeper view into the genomic sequence of Culex quinquefasciatus. PLoS ONE 2012, 7, e30770. [CrossRef] [PubMed]

73. Palatini, U.; Masri, R.A.; Cosme, L.V.; Koren, S.; Thibaud-Nissen, F.; Biedler, J.K.; Krsticevic, F.; Johnston, J.S.; Halbach, R.; Crawford, J.E.; et al. Improved reference genome of the arboviral vector Aedes albopictus. Genome Biol. 2020, 21. [CrossRef] [PubMed]

74. Luo, S.; Lu, J. Silencing of Transposable Elements by piRNAs in Drosophila: An Evolutionary Perspective. Genom. Proteom. Bioinform. 2017, 15, 164-176. [CrossRef]

75. Biryukova, I.; Ye, T. Endogenous siRNAs and piRNAs derived from transposable elements and genes in the malaria vector mosquito Anopheles gambiae. BMC Genom. 2015, 16, 278. [CrossRef]

76. Tassetto, M.; Kunitomi, M.; Whitfield, Z.J.; Dolan, P.T.; Sánchez-Vargas, I.; Garcia-Knight, M.; Ribiero, I.; Chen, T.; Olson, K.E.; Andino, R. Control of RNA viruses in mosquito cells through the acquisition of vDNA and endogenous viral elements. eLife 2019, 8. [CrossRef] [PubMed]

77. Saint-Leandre, B.; Capy, P.; Hua-Van, A.; Filée, J. piRNA and Transposon Dynamics in Drosophila: A Female Story. Genome Biol. Evol. 2020, 12, 931-947. [CrossRef] [PubMed]

78. Malone, C.D.; Brennecke, J.; Dus, M.; Stark, A.; Richard McCombie, W.; Sachidanandam, R.; Hannon, G.J. Specialized piRNA Pathways Act in Germline and Somatic Tissues of the Drosophila Ovary. Cell 2009, 137, 522-535. [CrossRef] [PubMed]

79. Jones, B.C.; Wood, J.G.; Chang, C.; Tam, A.D.; Franklin, M.J.; Siegel, E.R.; Helfand, S.L. A somatic piRNA pathway in the Drosophila fat body ensures metabolic homeostasis and normal lifespan. Nat. Commun. 2016, 7, 13856. [CrossRef]

80. Story, B.; Ma, X.; Ishihara, K.; Li, H.; Hall, K.; Peak, A.; Anoja, P.; Park, J.; Haug, J.; Blanchette, M.; et al. Defining the expression of piRNA and transposable elements in Drosophila ovarian germline stem cells and somatic support cells. Life Sci. Alliance 2019, 2, e201800211. [CrossRef] 
81. Quénerch'Du, E.; Anand, A.; Kai, T. The piRNA pathway is developmentally regulated during spermatogenesis in Drosophila. RNA 2016, 22, 1044-1054. [CrossRef] [PubMed]

82. Nagao, A.; Mituyama, T.; Huang, H.; Chen, D.; Siomi, M.C.; Siomi, H. Biogenesis pathways of piRNAs loaded onto AGO3 in the Drosophila testis. RNA 2010, 16, 2503-2515. [CrossRef] [PubMed]

83. Merkle, J.A.; Wittes, J.; Schüpbach, T. Signaling between somatic follicle cells and the germline patterns the egg and embryo of Drosophila. Curr. Top. Dev. Biol. 2020, 140, 55-86. [CrossRef] [PubMed]

84. Lehmann, R. Germ Plasm Biogenesis-An Oskar-Centric Perspective. Curr. Top. Dev. Biol. 2016, 116, 679-707. [CrossRef] [PubMed]

85. Venkei, Z.G.; Choi, C.P.; Feng, S.; Chen, C.; Jacobsen, S.E.; Kim, J.K.; Yamashita, Y.M. A kinesin Klp10A mediates cell cycle-dependent shuttling of Piwi between nucleus and nuage. PLoS Genet. 2020, 16, e1008648. [CrossRef] [PubMed]

86. Dong, J.; Wang, X.; Cao, C.; Wen, Y.; Sakashita, A.; Chen, S.; Zhang, J.; Zhang, Y.; Zhou, L.; Luo, M.; et al. UHRF1 suppresses retrotransposons and cooperates with PRMT5 and PIWI proteins in male germ cells. Nat. Commun. 2019, 10, 4705. [CrossRef] [PubMed]

87. Yoshimura, T.; Watanabe, T.; Kuramochi-Miyagawa, S.; Takemoto, N.; Shiromoto, Y.; Kudo, A.; Kanai-Azuma, M.; Tashiro, F.; Miyazaki, S.; Katanaya, A.; et al. Mouse GTSF1 is an essential factor for secondary piRNA biogenesis. EMBO Rep. 2018, 19. [CrossRef]

88. Wu, P.-H.; Fu, Y.; Cecchini, K.; Özata, D.M.; Arif, A.; Yu, T.; Colpan, C.; Gainetdinov, I.; Weng, Z.; Zamore, P.D. The evolutionarily conserved piRNA-producing locus pi6 is required for male mouse fertility. Nat. Genet. 2020, 52, 728-739. [CrossRef]

89. Shiromoto, Y.; Kuramochi-Miyagawa, S.; Nagamori, I.; Chuma, S.; Arakawa, T.; Nishimura, T.; Hasuwa, H.; Tachibana, T.; Ikawa, M.; Nakano, T. GPAT2 is required for piRNA biogenesis, transposon silencing, and maintenance of spermatogonia in mice. Boil. Reprod. 2019, 101, 248-256. [CrossRef]

90. Choi, C.P.; Tay, R.J.; Starostik, M.R.; Feng, S.; Moresco, J.J.; Montgomery, B.E.; Xu, E.; Hammonds, M.A.; Schatz, M.C.; Montgomery, T.A.; et al. SNPC-1.3 is a sex-specific transcription factor that drives male piRNA expression in C. elegans. bioRxiv 2020. [CrossRef]

91. Arensburger, P.; Hice, R.H.; Wright, J.A.; Craig, N.L.; Atkinson, P.W. The mosquito Aedes aegypti has a large genome size and high transposable element load but contains a low proportion of transposon-specific piRNAs. BMC Genom. 2011, 12, 606. [CrossRef] [PubMed]

92. Liu, P.; Dong, Y.; Gu, J.; Puthiyakunnon, S.; Wu, Y.; Chen, X.-G. Developmental piRNA profiles of the invasive vector mosquito Aedes albopictus. Parasit. Vectors 2016, 9, 524. [CrossRef] [PubMed]

93. Wong, W.Y.; Simakov, O.; Bridge, D.M.; Cartwright, P.; Bellantuono, A.J.; Kuhn, A.; Holstein, T.W.; David, C.N.; Steele, R.E.; Martínez, D.E. Expansion of a single transposable element family is associated with genome-size increase and radiation in the genus Hydra. Proc. Natl. Acad. Sci. USA 2019, 116, 22915-22917. [CrossRef] [PubMed]

94. Talla, V.; Suh, A.; Kalsoom, F.; Dincă, V.; Vila, R.; Friberg, M.; Wiklund, C.; Backström, N. Rapid Increase in Genome Size as a Consequence of Transposable Element Hyperactivity in Wood-White (Leptidea) Butterflies. Genome Boil. Evol. 2017, 9, 2491-2505. [CrossRef]

95. Akbari, O.S.; Antoshechkin, I.; Amrhein, H.; Williams, B.; Diloreto, R.; Sandler, J.; Hay, B.A. The developmental transcriptome of the mosquito Aedes aegypti, an invasive species and major arbovirus vector. G3 2013, 3, 1493-1509. [CrossRef]

96. Halbach, R.; Miesen, P.; Joosten, J.; Taşköprü, E.; Rondeel, I.; Pennings, B.; Vogels, C.B.F.; Merkling, S.H.; Koenraadt, C.J.; Lambrechts, L.; et al. A satellite repeat-derived piRNA controls embryonic development of Aedes. Nature 2020, 580, 274-277. [CrossRef]

97. Rouget, C.; Papin, C.; Boureux, A.; Meunier, A.-C.; Franco, B.; Robine, N.; Lai, E.C.; Pelisson, A.; Simonelig, M. Maternal mRNA deadenylation and decay by the piRNA pathway in the early Drosophila embryo. Nature 2010, 467, 1128-1132. [CrossRef]

98. Vourekas, A.; Alexiou, P.; Vrettos, N.; Maragkakis, M.; Mourelatos, Z. Sequence-dependent but not sequence-specific piRNA adhesion traps mRNAs to the germ plasm. Nature 2016, 531, 390-394. [CrossRef]

99. Barckmann, B.; Pierson, S.; Dufourt, J.; Papin, C.; Armenise, C.; Port, F.; Grentzinger, T.; Chambeyron, S.; Baronian, G.; Desvignes, J.-P.; et al. Aubergine iCLIP Reveals piRNA-Dependent Decay of mRNAs Involved in Germ Cell Development in the Early Embryo. Cell Rep. 2015, 12, 1205-1216. [CrossRef] 
100. Girardi, E.; Miesen, P.; Pennings, B.; Frangeul, L.; Saleh, M.-C.; van Rij, R.P. Histone-derived piRNA biogenesis depends on the ping-pong partners Piwi5 and Ago3 in Aedes aegypti. Nucleic Acids Res. 2017, 45, 4881-4892. [CrossRef]

101. Betting, V.; Joosten, J.; Halbach, R.; Thaler, M.; Miesen, P.; Van Rij, R.P. A regulatory network of a piRNA and lncRNA initiates responder and trailer piRNA formation during embryonic development of Aedes mosquitoes. bioRxiv 2020. [CrossRef]

102. Lau, N.C.; Robine, N.; Martin, R.; Chung, W.J.; Niki, Y.; Berezikov, E.; Lai, E.C. Abundant primary piRNAs, endo-siRNAs, and microRNAs in a Drosophila ovary cell line. Genome Res. 2009, 19, 1776-1785. [CrossRef] [PubMed]

103. Saito, K.; Inagaki, S.; Mituyama, T.; Kawamura, Y.; Ono, Y.; Sakota, E.; Kotani, H.; Asai, K.; Siomi, H.; Siomi, M.C. A regulatory circuit for piwi by the large Maf gene traffic jam in Drosophila. Nature 2009, 461, 1296-1299. [CrossRef]

104. Fagegaltier, D.; Falciatori, I.; Czech, B.; Castel, S.; Perrimon, N.; Simcox, A.; Hannon, G.J. Oncogenic transformation of Drosophila somatic cells induces a functional piRNA pathway. Genes Dev. 2016, 30, 1623-1635. [CrossRef]

105. Vrettos, N.; Maragkakis, M.; Alexiou, P.; Mourelatos, Z. Kc167, a widely used Drosophila cell line, contains an active primary piRNA pathway. RNA 2017, 23, 108-118. [CrossRef] [PubMed]

106. Wen, J.; Mohammed, J.; Bortolamiol-Becet, D.; Tsai, H.; Robine, N.; Westholm, J.O.; Ladewig, E.; Dai, Q.; Okamura, K.; Flynt, A.S.; et al. Diversity of miRNAs, siRNAs, and piRNAs across 25 Drosophila cell lines. Genome Res. 2014, 24, 1236-1250. [CrossRef]

107. Fu, Y.; Yang, Y.; Zhang, H.; Farley, G.; Wang, J.; Quarles, K.A.; Weng, Z.; Zamore, P.D. The genome of the Hi5 germ cell line from, an agricultural pest and novel model for small RNA biology. eLife 2018, 7. [CrossRef]

108. Kawaoka, S.; Hayashi, N.; Suzuki, Y.; Abe, H.; Sugano, S.; Tomari, Y.; Shimada, T.; Katsuma, S. The Bombyx ovary-derived cell line endogenously expresses PIWI/PIWI-interacting RNA complexes. RNA 2009, 15, 1258-1264. [CrossRef]

109. Kawaoka, S.; Izumi, N.; Katsuma, S.; Tomari, Y. $3^{\prime}$ end formation of PIWI-interacting RNAs in vitro. Mol. Cell 2011, 43, 1015-1022. [CrossRef]

110. Honda, S.; Kirino, Y.; Maragkakis, M.; Alexiou, P.; Ohtaki, A.; Murali, R.; Mourelatos, Z.; Kirino, Y. Mitochondrial protein BmPAPI modulates the length of mature piRNAs. RNA 2013, 19, 1405-1418. [CrossRef]

111. Goriaux, C.; Théron, E.; Brasset, E.; Vaury, C. History of the discovery of a master locus producing piRNAs: The flamenco/COM locus in Drosophila melanogaster. Front. Genet. 2014, 5, 257. [CrossRef] [PubMed]

112. McClintock, B. A cytological demonstration of the location of an interchange between two non-homologous chromosomes of zea mays. Proc. Natl. Acad. Sci. USA 1930, 16, 791-796. [CrossRef] [PubMed]

113. McClintock, B. The origin and behavior of mutable loci in maize. Proc. Natl. Acad. Sci. USA 1950, 36, 344-355. [CrossRef] [PubMed]

114. McClintock, B. The significance of responses of the genome to challenge. Science 1984, 226, 792-801. [CrossRef]

115. Kneuss, E.; Munafò, M.; Eastwood, E.L.; Deumer, U.-S.; Preall, J.B.; Hannon, G.J.; Czech, B. Specialization of the Drosophila nuclear export family protein Nxf3 for piRNA precursor export. Genes Dev. 2019, 33, 1208-1220. [CrossRef]

116. Ohtani, H.; Iwasaki, Y.W.; Shibuya, A.; Siomi, H.; Siomi, M.C.; Saito, K. DmGTSF1 is necessary for Piwi-piRISC-mediated transcriptional transposon silencing in the Drosophila ovary. Genes Dev. 2013, 27, 1656-1661. [CrossRef]

117. Li, C.; Vagin, V.V.; Lee, S.; Xu, J.; Ma, S.; Xi, H.; Seitz, H.; Horwich, M.D.; Syrzycka, M.; Honda, B.M.; et al. Collapse of Germline piRNAs in the Absence of Argonaute3 Reveals Somatic piRNAs in Flies. Cell 2009, 137, 509-521. [CrossRef]

118. Sato, K.; Siomi, M.C. The piRNA pathway in Drosophila ovarian germ and somatic cells. Proc. Jpn. Acad. Ser. B Phys. Biol. Sci. 2020, 96, 32-42. [CrossRef]

119. Zhang, Z.; Xu, J.; Koppetsch, B.S.; Wang, J.; Tipping, C.; Ma, S.; Weng, Z.; Theurkauf, W.E.; Zamore, P.D. Heterotypic piRNA Ping-Pong Requires Qin, a Protein with Both E3 Ligase and Tudor Domains. Mol. Cell 2011, 44, 1005. [CrossRef] 
120. Saito, K.; Nishida, K.M.; Mori, T.; Kawamura, Y.; Miyoshi, K.; Nagami, T.; Siomi, H.; Siomi, M.C. Specific association of Piwi with rasiRNAs derived from retrotransposon and heterochromatic regions in the Drosophila genome. Genes Dev. 2006, 20, 2214-2222. [CrossRef]

121. Guzzardo, P.M.; Muerdter, F.; Hannon, G.J. The piRNA pathway in flies: Highlights and future directions. Curr. Opin. Genet. Dev. 2013, 23, 44-52. [CrossRef] [PubMed]

122. Mohn, F.; Sienski, G.; Handler, D.; Brennecke, J. The rhino-deadlock-cutoff complex licenses noncanonical transcription of dual-strand piRNA clusters in Drosophila. Cell 2014, 157, 1364-1379. [CrossRef] [PubMed]

123. Klattenhoff, C.; Xi, H.; Li, C.; Lee, S.; Xu, J.; Khurana, J.S.; Zhang, F.; Schultz, N.; Koppetsch, B.S.; Nowosielska, A.; et al. The Drosophila HP1 Homolog Rhino Is Required for Transposon Silencing and piRNA Production by Dual-Strand Clusters. Cell 2009, 138, 1137-1149. [CrossRef] [PubMed]

124. Chen, Y.-C.A.; Stuwe, E.; Luo, Y.; Ninova, M.; Le Thomas, A.; Rozhavskaya, E.; Li, S.; Vempati, S.; Laver, J.D.; Patel, D.J.; et al. Cutoff Suppresses RNA Polymerase II Termination to Ensure Expression of piRNA Precursors. Mol. Cell 2016, 63, 97-109. [CrossRef] [PubMed]

125. Le Thomas, A.; Stuwe, E.; Li, S.; Du, J.; Marinov, G.; Rozhkov, N.; Chen, Y.-C.A.; Luo, Y.; Sachidanandam, R.; Toth, K.F.; et al. Transgenerationally inherited piRNAs trigger piRNA biogenesis by changing the chromatin of piRNA clusters and inducing precursor processing. Genes Dev. 2014, 28, 1667-1680. [CrossRef]

126. Pane, A.; Jiang, P.; Zhao, D.Y.; Singh, M.; Schüpbach, T. The Cutoff protein regulates piRNA cluster expression and piRNA production in theDrosophilagermline. EMBO J. 2011, 30, 4601-4615. [CrossRef]

127. Czech, B.; Preall, J.B.; McGinn, J.; Hannon, G.J. A Transcriptome-wide RNAi Screen in the Drosophila Ovary Reveals Factors of the Germline piRNA Pathway. Mol. Cell 2013, 50, 749-761. [CrossRef]

128. Zhang, Z.; Wang, J.; Schultz, N.; Zhang, F.; Parhad, S.S.; Tu, S.; Vreven, T.; Zamore, P.D.; Weng, Z.; Theurkauf, W.E. The HP1 homolog rhino anchors a nuclear complex that suppresses piRNA precursor splicing. Cell 2014, 157, 1353-1363. [CrossRef]

129. Dönertas, D.; Sienski, G.; Brennecke, J. Drosophila Gtsf1 is an essential component of the Piwi-mediated transcriptional silencing complex. Genes Dev. 2013, 27, 1693-1705. [CrossRef]

130. Goriaux, C.; Desset, S.; Renaud, Y.; Vaury, C.; Brasset, E. Transcriptional properties and splicing of the flamenco piRNA cluster. EMBO Rep. 2014, 15, 411-418. [CrossRef]

131. Brasset, E.; Taddei, A.R.; Arnaud, F.; Faye, B.; Fausto, A.M.; Mazzini, M.; Giorgi, F.; Vaury, C. Viral particles of the endogenous retrovirus ZAM from Drosophila melanogaster use a pre-existing endosome/exosome pathway for transfer to the oocyte. Retrovirology 2006, 3, 25. [CrossRef] [PubMed]

132. Chalvet, F.; Teysset, L.; Terzian, C.; Prud'Homme, N.; Santamaria, P.; Bucheton, A.; Pélisson, A. Proviral amplification of the Gypsy endogenous retrovirus of Drosophila melanogaster involves env-independent invasion of the female germline. EMBO J. 1999, 18, 2659-2669. [CrossRef] [PubMed]

133. Pélisson, A.; Song, S.U.; Prud'Homme, N.; Smith, P.A.; Bucheton, A.; Corces, V.G. Gypsy transposition correlates with the production of a retroviral envelope-like protein under the tissue-specific control of the Drosophila flamenco gene. EMBO J. 1994, 13, 4401-4411. [CrossRef] [PubMed]

134. Pelisson, A.; Mejlumian, L.; Robert, V.; Terzian, C.; Bucheton, A. Drosophila germline invasion by the endogenous retrovirus gypsy: Involvement of the viral env gene. Insect Biochem. Mol. Biol. 2002, 32, 1249-1256. [CrossRef]

135. Sokolova, O.A.; Mikhaleva, E.A.; Kharitonov, S.L.; Abramov, Y.A.; Gvozdev, V.A.; Klenov, M.S. Special vulnerability of somatic niche cells to transposable element activation in Drosophila larval ovaries. Sci. Rep. 2020, 10. [CrossRef]

136. George, P.; Jensen, S.; Pogorelcnik, R.; Lee, J.; Xing, Y.; Brasset, E.; Vaury, C.; Sharakhov, I.V. Increased production of piRNAs from euchromatic clusters and genes in Anopheles gambiae compared with Drosophila melanogaster. Epigenetics Chromatin 2015, 8, 50. [CrossRef]

137. Aguiar, E.R.G.R.; de Almeida, J.P.P.; Queiroz, L.R.; Oliveira, L.S.; Olmo, R.P.; de Faria, I.J.d.S.; Imler, J.-L.; Gruber, A.; Matthews, B.J.; Marques, J.T. A single unidirectional piRNA cluster similar to the locus is the major source of EVE-derived transcription and small RNAs in mosquitoes. RNA 2020, 26, 581-594. [CrossRef]

138. Ishizu, H.; Kinoshita, T.; Hirakata, S.; Komatsuzaki, C.; Siomi, M.C. Distinct and Collaborative Functions of $\mathrm{Yb}$ and Armitage in Transposon-Targeting piRNA Biogenesis. Cell Rep. 2019, 27, 1822-1835.e8. [CrossRef]

139. Duc, C.; Yoth, M.; Jensen, S.; Mouniee, N.; Bergman, C.M.; Vaury, C.; Brasset, E. Trapping a somatic endogenous retrovirus into a germline piRNA cluster immunizes the germline against further invasion. Genome Biol. 2019, 20, 127. [CrossRef] 
140. Yu, B.; Lin, Y.A.; Parhad, S.S.; Jin, Z.; Ma, J.; Theurkauf, W.E.; Zhang, Z.Z.Z.; Huang, Y. Structural insights into Rhino-Deadlock complex for germline piRNA cluster specification. EMBO Rep. 2018, 19. [CrossRef]

141. Parhad, S.S.; Tu, S.; Weng, Z.; Theurkauf, W.E. Adaptive Evolution Leads to Cross-Species Incompatibility in the piRNA Transposon Silencing Machinery. Dev. Cell 2017, 43, 60-70.e5. [CrossRef] [PubMed]

142. Vermaak, D.; Henikoff, S.; Malik, H.S. Positive selection drives the evolution of rhino, a member of the heterochromatin protein 1 family in Drosophila. PLoS Genet. 2005, 1, 96-108. [CrossRef] [PubMed]

143. Le Thomas, A.; Rogers, A.K.; Webster, A.; Marinov, G.K.; Liao, S.E.; Perkins, E.M.; Hur, J.K.; Aravin, A.A.; Tóth, K.F. Piwi induces piRNA-guided transcriptional silencing and establishment of a repressive chromatin state. Genes Dev. 2013, 27, 390-399. [CrossRef] [PubMed]

144. Sienski, G.; Dönertas, D.; Brennecke, J. Transcriptional Silencing of Transposons by Piwi and Maelstrom and Its Impact on Chromatin State and Gene Expression. Cell 2012, 151, 964-980. [CrossRef]

145. Zhao, K.; Cheng, S.; Miao, N.; Xu, P.; Lu, X.; Zhang, Y.; Wang, M.; Ouyang, X.; Yuan, X.; Liu, W.; et al. A Pandas complex adapted for piRNA-guided transcriptional silencing and heterochromatin formation. Nat. Cell Biol. 2019, 21, 1261-1272. [CrossRef]

146. Ninova, M.; Chen, Y.-C.A.; Godneeva, B.; Rogers, A.K.; Luo, Y.; Fejes Tóth, K.; Aravin, A.A. Su(var)2-10 and the SUMO Pathway Link piRNA-Guided Target Recognition to Chromatin Silencing. Mol. Cell 2020, 77, 556-570.e6. [CrossRef]

147. ElMaghraby, M.F.; Andersen, P.R.; Puhringer, F.; Hohmann, U.; Meixner, K.; Lendl, T.; Tirian, L.; Brennecke, J. A Heterochromatin-Specific RNA Export Pathway Facilitates piRNA Production. Cell 2019, 178, 964-979.e20. [CrossRef]

148. Batki, J.; Schnabl, J.; Wang, J.; Handler, D.; Andreev, V.I.; Stieger, C.E.; Novatchkova, M.; Lampersberger, L.; Kauneckaite, K.; Xie, W.; et al. The nascent RNA binding complex SFiNX licenses piRNA-guided heterochromatin formation. Nat. Struct. Mol. Biol. 2019, 26, 720-731. [CrossRef]

149. Murano, K.; Iwasaki, Y.W.; Ishizu, H.; Mashiko, A.; Shibuya, A.; Kondo, S.; Adachi, S.; Suzuki, S.; Saito, K.; Natsume, T.; et al. Nuclear RNA export factor variant initiates piRNA-guided co-transcriptional silencing. EMBO J. 2019, 38, e102870. [CrossRef]

150. Fabry, M.H.; Ciabrelli, F.; Munafo, M.; Eastwood, E.L.; Kneuss, E.; Falciatori, I.; Falconio, F.A.; Hannon, G.J.; Czech, B. piRNA-guided co-transcriptional silencing coopts nuclear export factors. eLife 2019, 8. [CrossRef]

151. Mugat, B.; Nicot, S.; Varela-Chavez, C.; Jourdan, C.; Sato, K.; Basyuk, E.; Juge, F.; Siomi, M.C.; Pelisson, A.; Chambeyron, $\mathrm{S}$. The Mi-2 nucleosome remodeler and the Rpd3 histone deacetylase are involved in piRNA-guided heterochromatin formation. Nat. Commun. 2020, 11, 2818. [CrossRef]

152. Kordyukova, M.; Sokolova, O.; Morgunova, V.; Ryazansky, S.; Akulenko, N.; Glukhov, S.; Kalmykova, A. Nuclear Ccr4-Not mediates the degradation of telomeric and transposon transcripts at chromatin in the Drosophila germline. Nucleic Acids Res. 2020, 48, 141-156. [CrossRef] [PubMed]

153. Wang, Y.; Jin, B.; Liu, P.; Li, J.; Chen, X.; Gu, J. piRNA Profiling of Dengue Virus Type 2-Infected Asian Tiger Mosquito and Midgut Tissues. Viruses 2018, 10, 213. [CrossRef] [PubMed]

154. Lewis, S.H.; Salmela, H.; Obbard, D.J. Duplication and Diversification of Dipteran Argonaute Genes, and the Evolutionary Divergence of Piwi and Aubergine. Genome Biol. Evol. 2016, 8, 507-518. [CrossRef] [PubMed]

155. Miesen, P.; Girardi, E.; van Rij, R.P. Distinct sets of PIWI proteins produce arbovirus and transposon-derived piRNAs in Aedes aegypti mosquito cells. Nucleic Acids Res. 2015, 43, 6545-6556. [CrossRef]

156. Salter, J.D.; Bennett, R.P.; Smith, H.C. The APOBEC Protein Family: United by Structure, Divergent in Function. Trends Biochem. Sci. 2016, 41, 578-594. [CrossRef]

157. Milewska, A.; Kindler, E.; Vkovski, P.; Zeglen, S.; Ochman, M.; Thiel, V.; Rajfur, Z.; Pyrc, K. APOBEC3-mediated restriction of RNA virus replication. Sci. Rep. 2018, 8. [CrossRef]

158. Bruno, M.; Mahgoub, M.; Macfarlan, T.S. The Arms Race between KRAB-Zinc Finger Proteins and Endogenous Retroelements and Its Impact on Mammals. Annu. Rev. Genet. 2019, 53, 393-416. [CrossRef]

159. Jacobs, F.M.; Greenberg, D.; Nguyen, N.; Haeussler, M.; Ewing, A.D.; Katzman, S.; Paten, B.; Salama, S.R.; Haussler, D. An evolutionary arms race between KRAB zinc-finger genes ZNF91/93 and SVA/L1 retrotransposons. Nature 2014, 516, 242-245. [CrossRef]

160. Soleimani, S.; Valizadeh Arshad, Z.; Moradi, S.; Ahmadi, A.; Davarpanah, S.J.; Azimzadeh Jamalkandi, S. Small regulatory noncoding RNAs in Drosophila melanogaster: Biogenesis and biological functions. Brief. Funct. Genom. 2020, 19, 309-323. [CrossRef] 
161. Lau, N.C. Small RNAs in the animal gonad: Guarding genomes and guiding development. Int. J. Biochem. Cell Biol. 2010, 42, 1334-1347. [CrossRef] [PubMed]

162. Ghildiyal, M.; Zamore, P.D. Small silencing RNAs: An expanding universe. Nat. Rev. Genet. 2009, 10, 94-108. [CrossRef] [PubMed]

163. Kim, V.N.; Narry Kim, V.; Han, J.; Siomi, M.C. Biogenesis of small RNAs in animals. Nat. Rev. Mol. Cell Boil. 2009, 10, 126-139. [CrossRef] [PubMed]

164. Gainetdinov, I.; Colpan, C.; Arif, A.; Cecchini, K.; Zamore, P.D. A Single Mechanism of Biogenesis, Initiated and Directed by PIWI Proteins, Explains piRNA Production in Most Animals. Mol. Cell 2018, 71, 775-790.e5. [CrossRef]

165. Morazzani, E.M.; Wiley, M.R.; Murreddu, M.G.; Adelman, Z.N.; Myles, K.M. Production of virus-derived ping-pong-dependent piRNA-like small RNAs in the mosquito soma. PLoS Pathog. 2012, 8, e1002470. [CrossRef]

166. Hoa, N.T.; Keene, K.M.; Olson, K.E.; Zheng, L. Characterization of RNA interference in an Anopheles gambiae cell line. Insect Biochem. Mol. Boil. 2003, 33, 949-957. [CrossRef]

167. Joosten, J.; Miesen, P.; Taskopru, E.; Pennings, B.; Jansen, P.; Huynen, M.A.; Vermeulen, M.; Van Rij, R.P. The Tudor protein Veneno assembles the ping-pong amplification complex that produces viral piRNAs in Aedes mosquitoes. Nucleic Acids Res. 2019, 47, 2546-2559. [CrossRef]

168. Mohn, F.; Handler, D.; Brennecke, J. Noncoding RNA. piRNA-guided slicing specifies transcripts for Zucchini-dependent, phased piRNA biogenesis. Science 2015, 348, 812-817. [CrossRef]

169. Feltzin, V.L.; Khaladkar, M.; Abe, M.; Parisi, M.; Hendriks, G.-J.; Kim, J.; Bonini, N.M. The exonuclease Nibbler regulates age-associated traits and modulates piRNA length in Drosophila. Aging Cell 2015, 14, 443-452. [CrossRef]

170. Hayashi, R.; Schnabl, J.; Handler, D.; Mohn, F.; Ameres, S.L.; Brennecke, J. Genetic and mechanistic diversity of piRNA $3^{\prime}$-end formation. Nature 2016, 539, 588-592. [CrossRef]

171. Ge, D.T.; Wang, W.; Tipping, C.; Gainetdinov, I.; Weng, Z.; Zamore, P.D. The RNA-Binding ATPase, Armitage, Couples piRNA Amplification in Nuage to Phased piRNA Production on Mitochondria. Mol. Cell 2019, 74, 982-995.e6. [CrossRef] [PubMed]

172. Xiol, J.; Spinelli, P.; Laussmann, M.A.; Homolka, D.; Yang, Z.; Cora, E.; Coute, Y.; Conn, S.; Kadlec, J.; Sachidanandam, R.; et al. RNA clamping by Vasa assembles a piRNA amplifier complex on transposon transcripts. Cell 2014, 157, 1698-1711. [CrossRef] [PubMed]

173. Wenda, J.M.; Homolka, D.; Yang, Z.; Spinelli, P.; Sachidanandam, R.; Pandey, R.R.; Pillai, R.S. Distinct Roles of RNA Helicases MVH and TDRD9 in PIWI Slicing-Triggered Mammalian piRNA Biogenesis and Function. Dev. Cell 2017, 41, 623-637.e9. [CrossRef] [PubMed]

174. Han, B.W.; Wang, W.; Li, C.; Weng, Z.; Zamore, P.D. Noncoding RNA. piRNA-guided transposon cleavage initiates Zucchini-dependent, phased piRNA production. Science 2015, 348, 817-821. [CrossRef]

175. Yamashiro, H.; Siomi, M.C. PIWI-Interacting RNA in Drosophila: Biogenesis, Transposon Regulation, and Beyond. Chem. Rev. 2018, 118, 4404-4421. [CrossRef]

176. Wu, Q.; Luo, Y.; Lu, R.; Lau, N.; Lai, E.C.; Li, W.-X.; Ding, S.-W. Virus discovery by deep sequencing and assembly of virus-derived small silencing RNAs. Proc. Natl. Acad. Sci. USA 2010, 107, 1606-1611. [CrossRef]

177. Chotkowski, H.L.; Ciota, A.T.; Jia, Y.; Puig-Basagoiti, F.; Kramer, L.D.; Shi, P.-Y.; Glaser, R.L. West Nile virus infection of Drosophila melanogaster induces a protective RNAi response. Virology 2008, 377, 197-206. [CrossRef]

178. Zambon, R.A.; Vakharia, V.N.; Wu, L.P. RNAi is an antiviral immune response against a dsRNA virus in Drosophila melanogaster. Cell. Microbiol. 2006, 8, 880-889. [CrossRef]

179. Petit, M.; Mongelli, V.; Frangeul, L.; Blanc, H.; Jiggins, F.; Saleh, M.-C. piRNA pathway is not required for antiviral defense in Drosophila melanogaster. Proc. Natl. Acad. Sci. USA 2016, 113, E4218-E4227. [CrossRef]

180. Saito, K.; Siomi, M.C. Small RNA-Mediated Quiescence of Transposable Elements in Animals. Dev. Cell 2010, 19, 687-697. [CrossRef]

181. Rozhkov, N.V.; Aravin, A.A.; Zelentsova, E.S.; Schostak, N.G.; Sachidanandam, R.; McCombie, W.R.; Hannon, G.J.; Evgen'Ev, M.B. Small RNA-based silencing strategies for transposons in the process of invading Drosophila species. RNA 2010, 16, 1634-1645. [CrossRef] [PubMed] 
182. Czech, B.; Malone, C.D.; Zhou, R.; Stark, A.; Schlingeheyde, C.; Dus, M.; Perrimon, N.; Kellis, M.; Wohlschlegel, J.A.; Sachidanandam, R.; et al. An endogenous small interfering RNA pathway in Drosophila. Nature 2008, 453, 798-802. [CrossRef] [PubMed]

183. Shpiz, S.; Ryazansky, S.; Olovnikov, I.; Abramov, Y.; Kalmykova, A. Euchromatic transposon insertions trigger production of novel Pi- and endo-siRNAs at the target sites in the drosophila germline. PLoS Genet. 2014, 10, e1004138. [CrossRef]

184. Li, H. Induction and Suppression of RNA Silencing by an Animal Virus. Science 2002, 296, 1319-1321. [CrossRef]

185. Galiana-Arnoux, D.; Dostert, C.; Schneemann, A.; Hoffmann, J.A.; Imler, J.-L. Essential function in vivo for Dicer-2 in host defense against RNA viruses in drosophila. Nat. Immunol. 2006, 7, 590-597. [CrossRef]

186. van Rij, R.P.; Saleh, M.-C.; Berry, B.; Foo, C.; Houk, A.; Antoniewski, C.; Andino, R. The RNA silencing endonuclease Argonaute 2 mediates specific antiviral immunity in Drosophila melanogaster. Genes Dev. 2006, 20, 2985-2995. [CrossRef]

187. Wang, X.-H.; Aliyari, R.; Li, W.-X.; Li, H.-W.; Kim, K.; Carthew, R.; Atkinson, P.; Ding, S.-W. RNA interference directs innate immunity against viruses in adult Drosophila. Science 2006, 312, 452-454. [CrossRef]

188. Sabin, L.R.; Zhou, R.; Gruber, J.J.; Lukinova, N.; Bambina, S.; Berman, A.; Lau, C.-K.; Thompson, C.B.; Cherry, S. Ars2 regulates both miRNA- and siRNA-dependent silencing and suppresses RNA virus infection in Drosophila. Cell 2009, 138, 340-351. [CrossRef]

189. Tassetto, M.; Kunitomi, M.; Andino, R. Circulating Immune Cells Mediate a Systemic RNAi-Based Adaptive Antiviral Response in Drosophila. Cell 2017, 169, 314-325.e13. [CrossRef]

190. Harsh, S.; Ozakman, Y.; Kitchen, S.M.; Paquin-Proulx, D.; Nixon, D.F.; Eleftherianos, I. Dicer-2 Regulates Resistance and Maintains Homeostasis against Zika Virus Infection in Drosophila. J. Immunol. 2018, 201, 3058-3072. [CrossRef]

191. Nayak, A.; Berry, B.; Tassetto, M.; Kunitomi, M.; Acevedo, A.; Deng, C.; Krutchinsky, A.; Gross, J.; Antoniewski, C.; Andino, R. Cricket paralysis virus antagonizes Argonaute 2 to modulate antiviral defense in Drosophila. Nat. Struct. Mol. Biol. 2010, 17, 547-554. [CrossRef] [PubMed]

192. Martins, N.; Lemoine, A.; Santiago, E.; Paro, S.; Imler, J.-L.; Meignin, C. A Transgenic Flock House Virus Replicon Reveals an RNAi Independent Antiviral Mechanism Acting in Drosophila Follicular Somatic Cells. G3 2019, 9, 403-412. [CrossRef] [PubMed]

193. Soares, Z.G.; Gonçalves, A.N.A.; de Oliveira, K.P.V.; Marques, J.T. Viral RNA recognition by the Drosophila small interfering RNA pathway. Microbes Infect. 2014, 16, 1013-1021. [CrossRef] [PubMed]

194. Roy, M.; Viginier, B.; Saint-Michel, É.; Arnaud, F.; Ratinier, M.; Fablet, M. Viral infection impacts transposable element transcript amounts in Drosophila. Proc. Natl. Acad. Sci. USA 2020, 117, 12249-12257. [CrossRef] [PubMed]

195. Cheng, G.; Liu, Y.; Wang, P.; Xiao, X. Mosquito Defense Strategies against Viral Infection. Trends Parasitol. 2016, 32, 177-186. [CrossRef]

196. Goic, B.; Stapleford, K.A.; Frangeul, L.; Doucet, A.J.; Gausson, V.; Blanc, H.; Schemmel-Jofre, N.; Cristofari, G.; Lambrechts, L.; Vignuzzi, M.; et al. Virus-derived DNA drives mosquito vector tolerance to arboviral infection. Nat. Commun. 2016, 7, 1-10. [CrossRef]

197. Miesen, P.; Ivens, A.; Buck, A.H.; van Rij, R.P. Small RNA Profiling in Dengue Virus 2-Infected Aedes Mosquito Cells Reveals Viral piRNAs and Novel Host miRNAs. PLoS Negl. Trop. Dis. 2016, 10, e0004452. [CrossRef]

198. Göertz, G.; Miesen, P.; Overheul, G.; van Rij, R.; van Oers, M.; Pijlman, G. Mosquito Small RNA Responses to West Nile and Insect-Specific Virus Infections in Aedes and Culex Mosquito Cells. Viruses 2019, 11, 271. [CrossRef]

199. Belda, E.; Nanfack-Minkeu, F.; Eiglmeier, K.; Carissimo, G.; Holm, I.; Diallo, M.; Diallo, D.; Vantaux, A.; Kim, S.; Sharakhov, I.V.; et al. De novo profiling of RNA viruses in Anopheles malaria vector mosquitoes from forest ecological zones in Senegal and Cambodia. BMC Genom. 2019, 20, 664. [CrossRef]

200. Siu, R.W.C.; Fragkoudis, R.; Simmonds, P.; Donald, C.L.; Chase-Topping, M.E.; Barry, G.; Attarzadeh-Yazdi, G.; Rodriguez-Andres, J.; Nash, A.A.; Merits, A.; et al. Antiviral RNA interference responses induced by Semliki Forest virus infection of mosquito cells: Characterization, origin, and frequency-dependent functions of virus-derived small interfering RNAs. J. Virol. 2011, 85, 2907-2917. [CrossRef] 
201. Paradkar, P.N.; Trinidad, L.; Voysey, R.; Duchemin, J.-B.; Walker, P.J. Secreted Vago restricts West Nile virus infection in Culex mosquito cells by activating the Jak-STAT pathway. Proc. Natl. Acad. Sci. USA 2012, 109, 18915-18920. [CrossRef] [PubMed]

202. Rückert, C.; Prasad, A.N.; Garcia-Luna, S.M.; Robison, A.; Grubaugh, N.D.; Weger-Lucarelli, J.; Ebel, G.D. Small RNA responses of Culex mosquitoes and cell lines during acute and persistent virus infection. Insect Biochem. Mol. Biol. 2019, 109, 13-23. [CrossRef] [PubMed]

203. Weger-Lucarelli, J.; Rückert, C.; Grubaugh, N.D.; Misencik, M.J.; Armstrong, P.M.; Stenglein, M.D.; Ebel, G.D.; Brackney, D.E. Adventitious viruses persistently infect three commonly used mosquito cell lines. Virology 2018, 521, 175-180. [CrossRef] [PubMed]

204. Barreto-Vieira, D.F.; Jácome, F.C.; da Silva, M.A.N.; Caldas, G.C.; de Filippis, A.M.B.; de Sequeira, P.C.; de Souza, E.M.; Andrade, A.A.; Manso, P.P.d.A.; Trindade, G.F.; et al. Structural investigation of C6/36 and Vero cell cultures infected with a Brazilian Zika virus. PLOS ONE 2017, 12, e0184397. [CrossRef] [PubMed]

205. Buchman, A.; Gamez, S.; Li, M.; Antoshechkin, I.; Li, H.-H.; Wang, H.-W.; Chen, C.-H.; Klein, M.J.; Duchemin, J.-B.; Paradkar, P.N.; et al. Engineered resistance to Zika virus in transgenic Aedes aegypti expressing a polycistronic cluster of synthetic small RNAs. Proc. Natl. Acad. Sci. USA 2019, 116, 3656-3661. [CrossRef]

206. Wu, X.; Hong, H.; Yue, J.; Wu, Y.; Li, X.; Jiang, L.; Li, L.; Li, Q.; Gao, G.; Yang, X. Inhibitory effect of small interfering RNA on dengue virus replication in mosquito cells. Virol. J. 2010, 7, 270. [CrossRef]

207. Saldaña, M.A.; Etebari, K.; Hart, C.E.; Widen, S.G.; Wood, T.G.; Thangamani, S.; Asgari, S.; Hughes, G.L. Zika virus alters the microRNA expression profile and elicits an RNAi response in Aedes aegypti mosquitoes. PLoS Negl. Trop. Dis. 2017, 11, e0005760. [CrossRef]

208. Léger, P.; Lara, E.; Jagla, B.; Sismeiro, O.; Mansuroglu, Z.; Coppée, J.Y.; Bonnefoy, E.; Bouloy, M. Dicer-2and Piwi-mediated RNA interference in Rift Valley fever virus-infected mosquito cells. J. Virol. 2013, 87, 1631-1648. [CrossRef]

209. Holmes, E.C. The Evolution of Endogenous Viral Elements. Cell Host Microbe 2011, 10, 368-377. [CrossRef]

210. Katzourakis, A.; Gifford, R.J. Endogenous viral elements in animal genomes. PLoS Genet. 2010, 6, e1001191. [CrossRef]

211. Palatini, U.; Miesen, P.; Carballar-Lejarazu, R.; Ometto, L.; Rizzo, E.; Tu, Z.; van Rij, R.P.; Bonizzoni, M. Comparative genomics shows that viral integrations are abundant and express piRNAs in the arboviral vectors Aedes aegypti and Aedes albopictus. BMC Genom. 2017, 18, 512. [CrossRef] [PubMed]

212. Lequime, S.; Lambrechts, L. Discovery of flavivirus-derived endogenous viral elements in two Anopheles mosquito genomes supports the existence of Anopheles-associated insect-specific flaviviruses. Virus Evol. 2017, 3, vew035. [CrossRef] [PubMed]

213. Houé, V.; Bonizzoni, M.; Failloux, A.-B. Endogenous non-retroviral elements in genomes of Aedes mosquitoes and vector competence. Emerg. Microbes Infect. 2019, 8, 542-555. [CrossRef] [PubMed]

214. Lourenço-de-Oliveira, R.; Marques, J.T.; Sreenu, V.B.; Nten, C.A.; Guimarães, E.R.; Varjak, M.; Kohl, A.; Failloux, A.-B. Culex quinquefasciatus mosquitoes do not support replication of Zika virus. J. Gen. Virol. 2018, 99, 258-264. [CrossRef]

215. Ter Horst, A.M.; Nigg, J.C.; Dekker, F.M.; Falk, B.W. Endogenous Viral Elements Are Widespread in Arthropod Genomes and Commonly Give Rise to PIWI-Interacting RNAs. J. Virol. 2019, 93. [CrossRef]

216. Suzuki, Y.; Baidaliuk, A.; Miesen, P.; Frangeul, L.; Crist, A.B.; Merkling, S.H.; Fontaine, A.; Lequime, S.; Moltini-Conclois, I.; Blanc, H.; et al. Non-retroviral Endogenous Viral Element Limits Cognate Virus Replication in Aedes aegypti Ovaries. Curr. Biol. 2020. [CrossRef]

217. Dobzhansky, T. On the Sterility of the Interracial Hybrids in Drosophila Pseudoobscura. Proc. Natl. Acad. Sci. USA 1933, 19, 397-403. [CrossRef]

218. Dobzhansky, T. Role of the Autosomes in the Drosophila Pseudoobscura Hybrids. Proc. Natl. Acad. Sci. USA 1933, 19, 950-953. [CrossRef]

219. Dobzhansky, T. Studies on Hybrid Sterility. II. Localization of Sterility Factors in Drosophila Pseudoobscura Hybrids. Genetics 1936, 21, 113-135.

220. Palopoli, M.F.; Wu, C.I. Genetics of hybrid male sterility between Drosophila sibling species: A complex web of epistasis is revealed in interspecific studies. Trends Genet. 1995, 11, 10. [CrossRef] 
221. Di Giacomo, M.; Comazzetto, S.; Saini, H.; De Fazio, S.; Carrieri, C.; Morgan, M.; Vasiliauskaite, L.; Benes, V.; Enright, A.J.; O'Carroll, D. Multiple epigenetic mechanisms and the piRNA pathway enforce LINE1 silencing during adult spermatogenesis. Mol. Cell 2013, 50, 601-608. [CrossRef] [PubMed]

222. Kelleher, E.S.; Edelman, N.B.; Barbash, D.A. Drosophila interspecific hybrids phenocopy piRNA-pathway mutants. PLoS Biol. 2012, 10, e1001428. [CrossRef] [PubMed]

223. Rozhkov, N.V.; Hammell, M.; Hannon, G.J. Multiple roles for Piwi in silencing Drosophila transposons. Genes Dev. 2013, 27, 400-412. [CrossRef]

224. Erwin, A.A.; Galdos, M.A.; Wickersheim, M.L.; Harrison, C.C.; Marr, K.D.; Colicchio, J.M.; Blumenstiel, J.P. piRNAs Are Associated with Diverse Transgenerational Effects on Gene and Transposon Expression in a Hybrid Dysgenic Syndrome of D. virilis. PLoS Genet. 2015, 11, e1005332. [CrossRef]

225. Serrato-Capuchina, A.; Wang, J.; Earley, E.; Peede, D.; Isbell, K.; Matute, D.R. Paternally Inherited P-Element Copy Number Affects the Magnitude of Hybrid Dysgenesis in Drosophila simulans and D. melanogaster. Genome Biol. Evol. 2020, 12, 808-826. [CrossRef] [PubMed]

226. Hill, T.; Rosales-Stephens, H.-L.; Unckless, R.L. Rapid divergence of the copulation proteins in the Drosophila dunni group is associated with hybrid post-mating-prezygotic incompatibilities. bioRxiv 2020. [CrossRef]

227. Brennecke, J.; Malone, C.D.; Aravin, A.A.; Sachidanandam, R.; Stark, A.; Hannon, G.J. An epigenetic role for maternally inherited piRNAs in transposon silencing. Science 2008, 322, 1387-1392. [CrossRef]

228. Kidwell, M.G.; Kidwell, J.F.; Sved, J.A. Hybrid Dysgenesis in drosophila melanogaster: A Syndrome of Aberrant Traits Including Mutation, Sterility and Male Recombination. Genetics 1977, 86, 813-833.

229. Ota, R.; Kobayashi, S. Myc plays an important role in Drosophila P-M hybrid dysgenesis to eliminate germline cells with genetic damage. Commun. Biol. 2020, 3, 185. [CrossRef]

230. Kotov, A.A.; Adashev, V.E.; Godneeva, B.K.; Ninova, M.; Shatskikh, A.S.; Bazylev, S.S.; Aravin, A.A.; Olenina, L.V. piRNA silencing contributes to interspecies hybrid sterility and reproductive isolation in Drosophila melanogaster. Nucleic Acids Res. 2019, 47, 4255-4271. [CrossRef]

231. Desset, S.; Buchon, N.; Meignin, C.; Coiffet, M.; Vaury, C. In Drosophila melanogaster the COM Locus Directs the Somatic Silencing of Two Retrotransposons through both Piwi-Dependent and -Independent Pathways. PLoS ONE 2008, 3, e1526. [CrossRef] [PubMed]

232. Brookfield, J.F.Y. Genetic evidence for repression of somatic P element movements in Drosophila melanogaster consistent with a role for the KP element. Heredity 1996, 76, 384-391. [CrossRef] [PubMed]

233. Srivastav, S.P.; Kelleher, E.S. Paternal Induction of Hybrid Dysgenesis in Drosophila melanogaster Is Weakly Correlated with Both P-Element and hobo Element Dosage. G3 2017, 7, 1487-1497. [CrossRef] [PubMed]

234. Srivastav, S.P.; Rahman, R.; Ma, Q.; Pierre, J.; Bandyopadhyay, S.; Lau, N.C. Har-P, a short P-element variant, weaponizes P-transposase to severely impair Drosophila development. eLife 2019, 8. [CrossRef]

235. Itoh, M.; Boussy, I.A. Full-size P and KP elements predominate in wild Drosophila melanogaster. Genes Genet. Syst. 2002, 77, 259-267. [CrossRef]

236. Rasmusson, K.E.; Simmons, M.J.; Raymond, J.D.; McLarnon, C.F. Quantitative effects of P elements on hybrid dysgenesis in Drosophila melanogaster. Genetics 1990, 124, 647-662.

237. Kofler, R. Dynamics of Transposable Element Invasions with piRNA Clusters. Mol. Biol. Evol. 2019, 36, 1457-1472. [CrossRef]

238. Kelleher, E.S.; Azevedo, R.B.R.; Zheng, Y. The Evolution of Small-RNA-Mediated Silencing of an Invading Transposable Element. Genome Biol. Evol. 2018, 10, 3038-3057. [CrossRef]

239. Kofler, R. piRNA clusters need a minimum size to control transposable element invasions. Genome Biol. Evol. 2020, 12, 736-749. [CrossRef]

240. Bonnet, D.D. The hybridization of Aedes aegypti and Aedes albopictus in Hawaii. Proc. Hawaii Entomol. Soc. 1950, 14, 35-39.

241. Harper, J.P.; Paulson, S.L. Reproductive isolation between Florida strains of Aedes aegypti and Aedes albopictus. J. Am. Mosq. Control Assoc. 1994, 10, 88-92. [PubMed]

242. Lanzaro, G.C.; Narang, S.K.; Mitchell, S.E.; Kaiser, P.E.; Seawright, J.A. Hybrid Male Sterility in Crosses Between Field and Laboratory Strains of Anopheles quadrimaculatus (Say) (Diptera: Culicidae). J. Med. Entomol. 1988, 25, 248-255. [CrossRef] [PubMed]

243. Liang, J.; Sharakhov, I.V. Premeiotic and meiotic failures lead to hybrid male sterility in the Anopheles gambiae complex. Proc. Biol. Sci. 2019, 286, 20191080. [CrossRef] [PubMed] 
244. Slotman, M.; della Torre, A.; Powell, J.R. The Genetics of Inviability and Male Sterility in Hybrids between Anopheles gambiae and An. arabiensis. Genetics 2004, 167, 275-287. [CrossRef]

245. Slotman, M.; della Torre, A.; Powell, J.R. Female sterility in hybrids between Anopheles gambiae and A. arabiensis, and the causes of Haldane's rule. Evolution 2005, 59, 1016-1026. [CrossRef] [PubMed]

246. Mathiopoulos, K.D.; della Torre, A.; Predazzi, V.; Petrarca, V.; Coluzzi, M. Cloning of inversion breakpoints in the Anopheles gambiae complex traces a transposable element at the inversion junction. Proc. Natl. Acad. Sci. USA 1998, 95, 12444-12449. [CrossRef] [PubMed]

247. White, B.J.; Collins, F.H.; Besansky, N.J. Evolution of Anopheles gambiae in Relation to Humans and Malaria. Annu. Rev. Ecol. Evol. Syst. 2011, 42, 111-132. [CrossRef]

248. Aravin, A.A.; Vagin, V.V.; Rozovsky, Y.M.; Gvozdev, V.A. Inhibition of Gene Expression by Homologous Double-Stranded RNA in a Drosophila melanogasterCell Culture. Russ. J. Genet. 2001, 37, 639-642. [CrossRef]

249. Aravin, A.A.; Naumova, N.M.; Tulin, A.V.; Vagin, V.V.; Rozovsky, Y.M.; Gvozdev, V.A. Double-stranded RNA-mediated silencing of genomic tandem repeats and transposable elements in the D. melanogaster germline. Curr. Biol. 2001, 11, 1017-1027. [CrossRef]

250. Aravin, A.A.; Klenov, M.S.; Vagin, V.V.; Rozovskii, Y.M.; Gvozdev, V.A. Role of double-stranded RNA in eukaryotic gene silencing. Mol. Biol. 2002, 36, 180-188. [CrossRef]

251. Aravin, A.A.; Klenov, M.S.; Vagin, V.V.; Bantignies, F.; Cavalli, G.; Gvozdev, V.A. Dissection of a natural RNA silencing process in the Drosophila melanogaster germ line. Mol. Cell. Biol. 2004, 24, 6742-6750. [CrossRef] [PubMed]

252. Klenov, M.S.; Lavrov, S.A.; Stolyarenko, A.D.; Ryazansky, S.S.; Aravin, A.A.; Tuschl, T.; Gvozdev, V.A. Repeat-associated siRNAs cause chromatin silencing of retrotransposons in the Drosophila melanogaster germline. Nucleic Acids Res. 2007, 35, 5430-5438. [CrossRef] [PubMed]

253. Vagin, V.V.; Sigova, A.; Li, C.; Seitz, H.; Gvozdev, V.; Zamore, P.D. A distinct small RNA pathway silences selfish genetic elements in the germline. Science 2006, 313, 320-324. [CrossRef] [PubMed]

254. Mirkovic-Hösle, M.; Förstemann, K. Transposon Defense by Endo-siRNAs, piRNAs and Somatic pilRNAs in Drosophila: Contributions of Loqs-PD and R2D2. PLoS ONE 2014, 9, e84994. [CrossRef] [PubMed]

255. Ghildiyal, M.; Seitz, H.; Horwich, M.D.; Li, C.; Du, T.; Lee, S.; Xu, J.; Kittler, E.L.W.; Zapp, M.L.; Weng, Z.; et al. Endogenous siRNAs derived from transposons and mRNAs in Drosophila somatic cells. Science 2008, 320, 1077-1081. [CrossRef]

256. Lim, D.-H.; Oh, C.-T.; Lee, L.; Hong, J.-S.; Noh, S.-H.; Hwang, S.; Kim, S.; Han, S.-J.; Lee, Y.S. The endogenous siRNA pathway in Drosophila impacts stress resistance and lifespan by regulating metabolic homeostasis. FEBS Lett. 2011, 585, 3079-3085. [CrossRef]

257. Hartig, J.V.; Förstemann, K. Loqs-PD and R2D2 define independent pathways for RISC generation in Drosophila. Nucleic Acids Res. 2011, 39, 3836-3851. [CrossRef]

258. Kawamura, Y.; Saito, K.; Kin, T.; Ono, Y.; Asai, K.; Sunohara, T.; Okada, T.N.; Siomi, M.C.; Siomi, H. Drosophila endogenous small RNAs bind to Argonaute 2 in somatic cells. Nature 2008, 453, 793-797. [CrossRef]

259. Okamura, K.; Chung, W.-J.; Ruby, J.G.; Guo, H.; Bartel, D.P.; Lai, E.C. The Drosophila hairpin RNA pathway generates endogenous short interfering RNAs. Nature 2008, 453, 803-806. [CrossRef]

260. Adelman, Z.N.; Anderson, M.A.E.; Liu, M.; Zhang, L.; Myles, K.M. Sindbis virus induces the production of a novel class of endogenous siRNAs in Aedes aegypti mosquitoes. Insect Mol. Biol. 2012, 21, 357-368. [CrossRef]

261. Castellano, L.; Rizzi, E.; Krell, J.; Di Cristina, M.; Galizi, R.; Mori, A.; Tam, J.; De Bellis, G.; Stebbing, J.; Crisanti, A.; et al. The germline of the malaria mosquito produces abundant miRNAs, endo-siRNAs, piRNAs and 29-nt small RNAs. BMC Genom. 2015, 16, 100. [CrossRef]

262. Myles, K.M.; Wiley, M.R.; Morazzani, E.M.; Adelman, Z.N. Alphavirus-derived small RNAs modulate pathogenesis in disease vector mosquitoes. Proc. Natl. Acad. Sci. USA 2008, 105, 19938-19943. [CrossRef]

263. Scott, J.C.; Brackney, D.E.; Campbell, C.L.; Bondu-Hawkins, V.; Hjelle, B.; Ebel, G.D.; Olson, K.E.; Blair, C.D. Comparison of dengue virus type 2-specific small RNAs from RNA interference-competent and -incompetent mosquito cells. PLoS Negl. Trop. Dis. 2010, 4, e848. [CrossRef]

264. Cirimotich, C.M.; Scott, J.C.; Phillips, A.T.; Geiss, B.J.; Olson, K.E. Suppression of RNA interference increases alphavirus replication and virus-associated mortality in Aedes aegypti mosquitoes. BMC Microbiol. 2009, 9, 49. [CrossRef] 
265. Brackney, D.E.; Scott, J.C.; Sagawa, F.; Woodward, J.E.; Miller, N.A.; Schilkey, F.D.; Mudge, J.; Wilusz, J.; Olson, K.E.; Blair, C.D.; et al. C6/36 Aedes albopictus cells have a dysfunctional antiviral RNA interference response. PLoS Negl. Trop. Dis. 2010, 4, e856. [CrossRef]

266. Keene, K.M.; Foy, B.D.; Sanchez-Vargas, I.; Beaty, B.J.; Blair, C.D.; Olson, K.E. RNA interference acts as a natural antiviral response to O'nyong-nyong virus (Alphavirus; Togaviridae) infection of Anopheles gambiae. Proc. Natl. Acad. Sci. USA 2004, 101, 17240-17245. [CrossRef]

267. Sánchez-Vargas, I.; Scott, J.C.; Katherine Poole-Smith, B.; Franz, A.W.E.; Barbosa-Solomieu, V.; Wilusz, J.; Olson, K.E.; Blair, C.D. Dengue Virus Type 2 Infections of Aedes aegypti Are Modulated by the Mosquito's RNA Interference Pathway. PLoS Pathog. 2009, 5, e1000299. [CrossRef]

268. Bernhardt, S.A.; Simmons, M.P.; Olson, K.E.; Beaty, B.J.; Blair, C.D.; Black, W.C. Rapid intraspecific evolution of miRNA and siRNA genes in the mosquito Aedes aegypti. PLoS ONE 2012, 7, e44198. [CrossRef]

269. Obbard, D.J.; Jiggins, F.M.; Halligan, D.L.; Little, T.J. Natural selection drives extremely rapid evolution in antiviral RNAi genes. Curr. Biol. 2006, 16, 580-585. [CrossRef]

270. van Mierlo, J.T.; Overheul, G.J.; Obadia, B.; van Cleef, K.W.R.; Webster, C.L.; Saleh, M.-C.; Obbard, D.J.; van Rij, R.P. Novel Drosophila viruses encode host-specific suppressors of RNAi. PLoS Pathog. 2014, 10, e1004256. [CrossRef]

271. Yen, P.-S.; James, A.; Li, J.-C.; Chen, C.-H.; Failloux, A.-B. Synthetic miRNAs induce dual arboviral-resistance phenotypes in the vector mosquito Aedes aegypti. Commun. Biol. 2018, 1, 11. [CrossRef] [PubMed]

272. Franz, A.W.E.; Sanchez-Vargas, I.; Adelman, Z.N.; Blair, C.D.; Beaty, B.J.; James, A.A.; Olson, K.E. Engineering RNA interference-based resistance to dengue virus type 2 in genetically modified Aedes aegypti. Proc. Natl. Acad. Sci. USA 2006, 103, 4198-4203. [CrossRef] [PubMed]

273. Moyes, C.L.; Athinya, D.K.; Seethaler, T.; Battle, K.E.; Sinka, M.; Hadi, M.P.; Hemingway, J.; Coleman, M.; Hancock, P.A. Evaluating insecticide resistance across African districts to aid malaria control decisions. Proc. Natl. Acad. Sci. USA 2020, 117, 22042-22050. [CrossRef] [PubMed]

274. Lin, H.; Spradling, A.C. Germline Stem Cell Division and Egg Chamber Development in Transplanted Drosophila Germaria. Dev. Biol. 1993, 159, 140-152. [CrossRef] [PubMed]

275. Cox, D.N.; Chao, A.; Baker, J.; Chang, L.; Qiao, D.; Lin, H. A novel class of evolutionarily conserved genes defined by piwi are essential for stem cell self-renewal. Genes Dev. 1998, 12, 3715-3727. [CrossRef]

276. Cox, D.N.; Chao, A.; Lin, H. Piwi encodes a nucleoplasmic factor whose activity modulates the number and division rate of germline stem cells. Development 2000, 127, 503-514.

277. Matthews, B.J.; Vosshall, L.B. How to turn an organism into a model organism in 10 'easy' steps. J. Exp. Biol. 2020, 223, jeb218198. [CrossRef]

278. Xu, J.; Ren, X.; Sun, J.; Wang, X.; Qiao, H.-H.; Xu, B.-W.; Liu, L.-P.; Ni, J.-Q. A Toolkit of CRISPR-Based Genome Editing Systems in Drosophila. J. Genet. Genom. 2015, 42, 141-149. [CrossRef]

279. Yamaguchi, M.; Yoshida, H. Drosophila as a Model Organism. Adv. Exp. Med. Biol. 2018, 1076, 1-10. [CrossRef]

280. Buchman, A.B.; Brogan, D.J.; Sun, R.; Yang, T.; Hsu, P.D.; Akbari, O.S. Programmable RNA Targeting Using CasRx in Flies. CRISPR J. 2020, 3, 164-176. [CrossRef]

281. Kandul, N.P.; Liu, J.; Hsu, A.D.; Hay, B.A.; Akbari, O.S. A novel drug-inducible sex-separation technique for insects. Nat. Commun. 2020. [CrossRef] [PubMed]

282. Kandul, N.P.; Liu, J.; Buchman, A.; Gantz, V.M.; Bier, E.; Akbari, O.S. Assessment of a Split Homing Based Gene Drive for Efficient Knockout of Multiple Genes. G3 2020, 10, 827-837. [CrossRef] [PubMed]

283. Kozeretska, I.A.; Shulha, V.I.; Serga, S.V.; Rozhok, A.I.; Protsenko, O.V.; Lau, N.C. A rapid change in P-element-induced hybrid dysgenesis status in Ukrainian populations of Drosophila melanogaster. Biol. Lett. 2018, 14, 20180184. [CrossRef] [PubMed]

284. Greppi, C.; Laursen, W.J.; Budelli, G.; Chang, E.C.; Daniels, A.M.; van Giesen, L.; Smidler, A.L.; Catteruccia, F.; Garrity, P.A. Mosquito heat seeking is driven by an ancestral cooling receptor. Science 2020, 367, 681-684. [CrossRef] [PubMed]

285. Jové, V.; Gong, Z.; Hol, F.J.H.; Zhao, Z.; Sorrells, T.R.; Carroll, T.S.; Prakash, M.; McBride, C.S.; Vosshall, L.B. The Taste of Blood in Mosquitoes. bioRxiv 2020. [CrossRef]

286. Denlinger, D.L.; Armbruster, P.A. Mosquito Diapause. Annu. Rev. Entomol. 2014, 59, 73-93. [CrossRef]

287. Li, M.; Yang, T.; Kandul, N.P.; Bui, M.; Gamez, S.; Raban, R.; Bennett, J.; Lanzaro, G.C.; Schmidt, H.; Lee, Y.; et al. Development of a confinable gene drive system in the human disease vector. eLife 2020, 9. [CrossRef] 
288. Li, M.; Bui, M.; Yang, T.; Bowman, C.S.; White, B.J.; Akbari, O.S. Germline Cas9 expression yields highly efficient genome engineering in a major worldwide disease vector, Aedes aegypti. Proc. Natl. Acad. Sci. USA 2017, 114, E10540-E10549. [CrossRef]

289. Li, M.; Akbari, O.S.; White, B.J. Highly Efficient Site-Specific Mutagenesis in Malaria Mosquitoes Using CRISPR. G3 2018, 8, 653-658. [CrossRef]

290. Gantz, V.M.; Jasinskiene, N.; Tatarenkova, O.; Fazekas, A.; Macias, V.M.; Bier, E.; James, A.A. Highly efficient Cas9-mediated gene drive for population modification of the malaria vector mosquito Anopheles stephensi. Proc. Natl. Acad. Sci. USA 2015, 112, E6736-E6743. [CrossRef]

291. Gamez, S.; Antoshechkin, I.; Mendez-Sanchez, S.C.; Akbari, O.S. The Developmental Transcriptome of Aedes albopictus, a Major Worldwide Human Disease Vector. G3 2020, 10, 1051-1062. [CrossRef] [PubMed]

292. Chakraborty, M.; Ramaiah, A.; Adolfi, A.; Halas, P.; Kaduskar, B.; Ngo, L.T.; Jayaprasad, S.; Paul, K.; Whadgar, S.; Srinivasan, S.; et al. Hidden features of the malaria vector mosquito, Anopheles stephensi, revealed by a high-quality reference genome. bioRxiv 2020. [CrossRef]

293. Casier, K.; Delmarre, V.; Gueguen, N.; Hermant, C.; Viode, E.; Vaury, C.; Ronsseray, S.; Brasset, E.; Teysset, L.; Boivin, A. Environmentally-induced epigenetic conversion of a piRNA cluster. eLife 2019, 8. [CrossRef] [PubMed]

294. Chaverra-Rodriguez, D.; Macias, V.M.; Hughes, G.L.; Pujhari, S.; Suzuki, Y.; Peterson, D.R.; Kim, D.; McKeand, S.; Rasgon, J.L. Targeted delivery of CRISPR-Cas9 ribonucleoprotein into arthropod ovaries for heritable germline gene editing. Nat. Commun. 2018, 9, 3008. [CrossRef] [PubMed]

295. Macias, V.M.; McKeand, S.; Chaverra-Rodriguez, D.; Hughes, G.L.; Fazekas, A.; Pujhari, S.; Jasinskiene, N.; James, A.A.; Rasgon, J.L. Cas9-Mediated Gene-Editing in the Malaria Mosquito Anopheles stephensi by ReMOT Control. G3 2020, 10, 1353-1360. [CrossRef] [PubMed]

296. Chaverra-Rodriguez, D.; Dalla Benetta, E.; Heu, C.C.; Rasgon, J.L.; Ferree, P.M.; Akbari, O.S. Germline mutagenesis of Nasonia vitripennis through ovarian delivery of CRISPR-Cas9 ribonucleoprotein. Insect Mol. Biol. 2020. [CrossRef] [PubMed]

297. Schnettler, E.; Donald, C.L.; Stacey, H.; Watson, M.; Siu, R.W.C.; McFarlane, M.; Fazakerley, J.K.; Kohl, A.; Fragkoudis, R. Knockdown of piRNA pathway proteins results in enhanced Semliki Forest virus production in mosquito cells. J. Gen. Virol. 2013, 94, 1680-1689. [CrossRef]

298. Varjak, M.; Dietrich, I.; Sreenu, V.B.; Till, B.E.; Merits, A.; Kohl, A.; Schnettler, E. Spindle-E Acts Antivirally Against Alphaviruses in Mosquito Cells. Viruses 2018, 10, 88. [CrossRef]

299. Varjak, M.; Donald, C.L.; Mottram, T.J.; Sreenu, V.B.; Merits, A.; Maringer, K.; Schnettler, E.; Kohl, A. Characterization of the Zika virus induced small RNA response in Aedes aegypti cells. PLoS Negl. Trop. Dis. 2017, 11, e0006010. [CrossRef]

(C) 2020 by the authors. Licensee MDPI, Basel, Switzerland. This article is an open access article distributed under the terms and conditions of the Creative Commons Attribution (CC BY) license (http://creativecommons.org/licenses/by/4.0/). 